STUDLA HISTORYCZNE

R. LX, 2017, ₹. 3 (239), s. 87-118

\title{
POLEMIKA
}

\author{
Mateusz Kosonowski
}

Uniwersytet Jagielloński, Kraków

\section{JESZCZE RAZ O NAJDAWNIEJSZYCH WIEKACH DZIEJÓW LUBLINA I O RZEKOMEJ XI-WIECZNEJ GENEZIE TAMTEJSZYCH STRUKTUR KOŚCIELNYCH}

\section{EPILOG DO DYSKUSJI Z JACKIEM CHACHAJEM ${ }^{1}$}

W ostatnich latach objawił się w polskiej historiografii chwalebny urodzaj na rozprawy, artykuły i pomniejsze studia poświęcone skomplikowanym i nierzadko enigmatycz-

\footnotetext{
Odbiorcom niniejszego artykułu należą się przed rozpoczęciem jego lektury stosowne wyjaśnienia. W 2014 r. trafiła do księgarń w Polsce, wchodząc tym samym w obieg czytelniczy, najnowsza książka naukowa Jacka Chachaja, Lublin - miasto Rychesy? Lubelskie sækice historyczne XI-XIV wieku, Wydawnictwo Werset, Lublin 2014, ss. 202+1 mapa (oraz wyd. II, uzupełnione o bibliografię, Lublin 2014, z identyczną paginacją kolejnych szkiców). Zapoznawszy się od razu dokładnie z tą publikacja i nabrawszy po drodze sporo wątpliwości co do zasadności ogłoszonych w niej rezultatów i propozycji badawczych, a także metodologicznej drogi dojścia do przedstawionych rozwiązań i hipotez, podałem do publicznej wiadomości tę garść własnych przemyśleń i spostrzeżeń w obszernej rozprawie recenzyjnej: Cay królowa Rycheza mogła coś wiedzieć o Lublinie? Na marginesie koncepcji powstania i rozwoju organizacji kościelnej w Lublinie w XI-XIV wieku pióra Jacka Chachaja, „Nasza Przeszłość” [dalej: NP] 124 (2015), s. 265-299. Korzystając ze standardowego prawa do repliki, wystapił z kolei z osobna, również dość obszerną, odpowiedzią na te moje zastrzeżenia J. Cha chaj: Jak nie nalešy zajmowá́ się historia. W odpowiedzi na recenzje Mateusza Kosonowskiego („,Czy królowa Rycheza mogła coś wiedziieć o Lublinie? Na marginesie koncepcji powstania i roz̨woju organizacji kościelnej w Lublinie w XI-XIV wieku pióra Jacka Chachaja"), NP 125 (2016), s. 309-324.

Z własną odpowiedzią na ten głos byłem gotowy już pod koniec września 2016 r., czemu wyraz dałem, składając niezwłocznie jej maszynopis do Redakcji „Naszej Przeszłości”. Zrywając z powszechnie zakorzenionym prawem recenzenta do odpowiedzi na replikę ze strony autora, respektowanym od dziesięcioleci na łamach już to polskich, już to zagranicznych periodyków naukowych, Redakcja nie wyraziła jednak chęci przyjęcia pod swój szyld tego ostatniego artykułu, o czym zostałem poinformowany w osobnej, prywatnej korespondencji z 20 XII 2016 r.
} 
nym dziejom Lublina, zwłaszcza w ich najdawniejszym - średniowiecznym - etapie. Do rąk czytelników pragnących wniknąć w arkana owej problematyki trafiły więc zarówno pozycje podsumowujące stan naszej wiedzy w tym zakresie, jak również ujęcia nowatorskie, wnoszące do toczącej się już od dziesięcioleci dyskusji wiano nowych argumentów, hipotez i spostrzeżeń badawczych. Wśród wszystkich tych wypowiedzi nie sposób nie dostrzec licznych studiów Jacka Chachaja, który od lat daje wyraz swoim zainteresowaniom historią lubelskiego ośrodka grodowego (a później miejskiego), jak również procesem powstania i rozwoju tamtejszych struktur kościelnych (głównie archidiakonalnych) ${ }^{2}$. Prócz wyszczególnionych rozpraw spod prasy drukarskiej wyszedł też niedawno zbiór dwunastu szkiców historycznych tego Autora, opatrzony tytułem Lublin - miasto Rycheay? Lubelskie szkeice historyczne XI-XIV wieku, dotykający najsłabiej

Ponieważ nie istnieje zasadniczo praktyka przenoszenia dyskusji toczonych na forum jednego czasopisma na łamy drugiego, tekst ten zmuszony był przez pewien czas oczekiwać na ogłoszenie drukiem w tece autorskiej niżej podpisanego. Znalazła natomiast dla niego miejsce na swoich łamach Redakcja „Studiów Historycznych”, której za tę otwartość i gościnność składam serdeczne podziękowania.

Prezentowana obecnie odpowiedź została w swym zasadniczym zrębie zredagowana w sierpniu i wrześniu 2016 r.; narosłą od tamtej pory literaturę uwzględniam - o ile zachodzi taka konieczność - już tylko w przypisach. Całość tekstu, nie licząc rozwinięcia niektórych z poruszanych wątków, pozostawiam na ogół bez gruntownych zmian, kierując się postulatem zachowania wierności ówczesnemu stadium dyskusji.

2 Wymieniamy w porządku chronologicznym: J. Chachaj, Archidiakoni lubelscy w XV wieku, NP 111 (2009), s. 55-83; id em, Poczatki kościotón lubelskich w swietle legend i przekeazón historycznych, przedmowa C. Deptuła, Lublin 2010 (por. rec. P. Plisieckiego, Poczatki organizacji kościelnej w średniowiecznym Lublinie, „Roczniki Humanistyczne” [dalej: Rocz. Hum.] 59 (2011), z. 2, s. 249-263 oraz krótsza wersja - „Kwartalnik Historyczny” [dalej: Kw. Hist.] 119 (2012), nr 2, s. 377-381); idem, Blizej schizmatykón niž Krakowa. Archidiakonat lubelski w XV i XVI wieku, Lublin 2012; id em, Archidiakoni lubelscy do końca XIV wieku, [w:] Scientia et Fidelitate. Ksiega pamiatkowa Eny i Czesława Deptutów, profesorón Katolickiego Uniwersytetu Lubelskiego, red. T. Pan fil, Lublin 2013, s. 169-190; id em, Jeden cay dwa groby? Transformacja obrazu czasu i przestrzeni sakralnej Lublina w dziełach Jana D tugosza na prayktadzie dominikańskiego kościoła św. Stanistawa, Rocz. Hum. 61 (2014), z. 2, s. 41-60; idem, Tempo procesów urbanizacji i rozwoju sieci parafialnej w Lubelskiem w XV i XVI wieku, [w:] Scientia nibil est quam veritatis imago. Studia ofiarowane Profesorowi Ryszardowi Szcrygtowi w siedemdziesieciolecie urodzin, red. A. Soch ack a, P. Jusiak, Lublin 2014, s. 170183; id em, Ruskie tropy w średniowiecznym Lublinie, Rocz. Hum. 62 (2014), z. 7, s. 29-51; id e m, Najstarsze kościoly lubelskie, [w:] Ziemia - człowiek - sztuka. Interdyscyplinarne studia nad ziemia. Archeologia, bistoria, kultura, sztuka, red. U. Mazurczak, Lublin 2015, s. 375-412 oraz id em, Lubelski kościót pod wezwaniem śnietego Mikotaja w swietle źródet i literatury, „TEKA Komisji Historycznej Polskiej Akademii Nauk. Oddział w Lublinie" 12 (2015), s. 35-53. Własny wkład badawczy w proces naukowego rozpoznania genezy lokalnych struktur kościelnych (wraz z obszernym omówieniem dawniejszych w tym zakresie propozycji) syntetycznie charakteryzuje też sam zainteresowany w jednej ze swych ostatnich wypowiedzi: Poczattki lubelskiego ośrodka kościelnego, [w:] Lublin prz̨ez siedem wieków. Wydarzenia i ludzie, red. E. Niebielski, Lublin 2017, s. 165-199, tutaj w szczególności s. 177 i n. (przegląd historiografii) oraz s. 166, 186, 192 196 (z wyszczególnieniem indywidualnych osiagnięć autora). Por. jeszcze idem, Znaczenie nowoṡytnych przekeazón źródtonych dla badan nad dziejami Lublina w średniowieczu, [w:] Studia z dziejów Europy ŚrodkowoWschodniej, red. W. Bondyra, D. Kupisz, J. Ternes, L. Wierzbicki, Lublin 2018, s. 515-529. 
oświetlonego źródłowo odcinka dziejów średniowiecznego Lublina (od zalążków istnienia grodu aż po XIV stulecie) $)^{3}$.

Jakkolwiek J. Chachaj porusza w owym zbiorze różnorodna problematykę badawcza, jednakże zasadniczą osnową pokaźnej części Jego wywodów pozostaje pogląd, iż istnieją poważne przesłanki do wysunięcia hipotezy, że lubelski ośrodek grodowy ma jeszcze XI-wieczną metrykę (sprzed 1031 r.), a jego założycielki i zarazem fundatorki najstarszego tamtejszego kościoła (pw. św. Michała) dopatruje się Autor w osobie małżonki Mieszka II - królowej Rychezy ${ }^{4}$. W mniej lub bardziej ścisłej zależności od tego stanowiska pozostaje szereg Jego dalszych argumentów i propozycji, wśród których jednym tchem wymienimy m.in. alternatywne wobec dotychczasowych próby etymologizacji nazwy Lublin, a także rozważania nad: a) genezą świątyni pw. Trójcy Świętej na Wzgórzu Zamkowym (datowanej przezeń najpóźniej na schyłek rządów Kazimierza Odnowiciela, przed 1057 r.), b) domniemanym pobytem w Lublinie (i Kocku?) wygnanych z Kijowa córki i zięcia Rychezy - Gertrudy i Izjasława Jarosławowicza w połowie lat 70. XI w. oraz c) obecnością i obsługą liturgiczną najstarszej świątyni lubelskiej przez benedyktynów już w XI w. ${ }^{5}$ Ustawienie Rychezy w roli prawdopodobnej założycielki Lublina znakomicie wiąże się wreszcie z kolejnym stanowiskiem J. Chachaja, który - powołując się na wypowiedzi części partnerujących historykom w tej dyskusji archeologów - przyjmuje, iż pierwotnie istniał na tym terenie lokalny gród plemienny, zdobyty i zniszczony z rozkazu piastowskiego u schyłku X w., a następnie zastąpiony - najpierw przez prowizoryczne stanice, a później nowy, piastowski gród już w pierwszych dekadach XI stulecia. W takim symbiotycznym ujęciu obie te hipotezy nie tylko nie wchodzą ze sobą w konflikt, ale wydatnie się wspierają. Jeżeli określimy bowiem początek istnienia najstarszego grodu piastowskiego na pierwsze dekady XI w., to próby powiązania jego rodowodu z Rychezą i jej zabiegami potencjalnie zyskują dodatkową siłę przebicia ${ }^{6}$. Odrębne od postaci małżonki Mieszka II gałęzi w rozważaniach współtworzą natomiast pozostałe szkice o: formach pierwotnego zagospodarowania przestrzennego i zasięgu osadnictwa na północ od rzeki Czechówki, lokalizacji najstarszego kościoła parafialnego w topografii grodowej, długofalowym procesie lokacji miasta, najazdach nieprzyjacielskich na

\footnotetext{
Zob. J. Chachaj, Lublin - miasto Rycheay? (jw., przypis 1).

$4 \quad$ Ibidem, s. 13-49 (szkic pt. Lublin - miasto Rychezy? Czyli na bezdrożach szzzegótowych dociekań o poczatkach i wczesnych dziejach miasta nad Bystrayca), a zwł. s. 15-31 oraz 58-60, 199-200 (Zakończenie).

5 Ibidem, głównie s. 31-49, 49-58 (szkic pt. Czy Lublin pierwotnie nosit inna nazwę?), s. 109-128 (szkic pt. Lublin siedziba wygnanych ksiażat ruskich w drugiej połowie XI wieku?), s. 148-156 (szkic pt. Czy w Lublinie byli benedyk.tyni?) oraz we wnioskach i zakończeniu (s. 158, 199-200).

6 Ibidem, głównie s. 97-109 (szkic pt. Czy pržed XII wiekiem w Lublinie istniat gród?), s. 128-148 (szkic pt. Gdzie znajdowat sie najstarsyy lubelski gród doby państwowej?) oraz s. 157, 200.
} 
Lublin w 1288 r., a także - nie na ostatnim miejscu - o XIV-wiecznej genezie kościoła św. Mikołaja na wzgórzu Czwartek ${ }^{7}$.

Rzuca się zatem w oczy, iż praca J. Chachaja, jakkolwiek nie sytuuje się genologicznie wśród ujęć monograficznych, dostarcza jednak bogatego i w wielu miejscach nowatorskiego tworzywa do dyskusji nad najdawniejszymi wiekami Lublina, przez co zasługuje na wnikliwy i analityczny komentarz oraz weryfikację ze strony innych zainteresowanych badaczy $^{8}$. Komentarz taki zdecydowałem się dostarczyć w osobnym artykule recenzyjnym, ogłoszonym na łamach „Naszej Przeszłości”, w którym to po przedstawieniu racji Autora i ich szczegółowej krytyce przy użyciu świadectw źródłowych i wypowiedzi historiografii doszedłem do jednoznacznego wniosku, iż czyniąc nawet najdalej idące koncesje na rzecz rozmaitych dróg hipotetycznej rekonstrukcji czasów i wydarzeń minionych, ale biorąc też na poważnie zespół normatywnych prawideł metodycznego i metodologicznego konstruowania wywodów, nie mogę zająć wobec zdecydowanej większości wniosków i hipotez J. Chachaja aprobatywnego stanowiska. Wniosek ten niezmiennie uważam za słuszny i uzasadniony?

Obszerną odpowiedź na te poczynione spostrzeżenia i zastrzeżenia przygotował z kolei i ogłosił w następnym tomie tego periodyku J. Chachaj ${ }^{10}$, koncentrując swoja uwage już to na obronie własnych, wypowiedzianych wcześniej propozycji, już to na

Ibidem, s. 62-70 (szkic pt. Jak rzecrymiscie mygladała ,strefa zaczechowrianska” lubelskiego zespotu osadniczego w XI i XII wieku?), s. 70-97 (szkic pt. Jeszcrze o lokalizacji najstarszego lubelskiego kościoła parafialnego), s. 161-181 (szkice pt. Kwestia lokacji Lublina præeed 1317 rokiem oraz będacy niejako jego kontynuacja: Kto dokonat zamiany terenu na W agórzu Staromiejskim na wieś Driesiata zarchidiakonem lubelskim?), s. 181-190 (O postawie zatogi grodu lubelskiego w 1288 roku), s. 190-197 (szkic pt. Jeszcze o poczatkach kościoła św. Mikotaja) oraz w formie wniosków (s. 158, 200-201).

8 Sam autor, wyjaśniając zasadnicze cele poznawcze, które postawił swojej pracy, upatruje ich głównie w skierowaniu uwagi odbiorców na fakt, że „,wprowadzając mniej znane późniejsze przekazy lub poddając znane źródła nowym interpretacjom, można zbudować nowe hipotezy o początkach Lublina, w gruncie rzeczy wcale nie mniej prawdopodobne niż część pomysłów, które zdobyły uznanie wśród badaczy. W kwestii początków lubelskiego ośrodka kościelnego praca zwraca uwagę na możliwość powstania pierwszych świątyń w Lublinie (zwłaszcza kaplicy grodowej oraz hipotetycznej świątyni w rejonie późniejszego klasztoru dominikańskiego) już w drugiej połowie XI wieku” (J. Chachaj, Poczatki lubelskiego ośrodka, s. 192-193).

9 Zob. M. Kosonowski, Czy królowa Rycheza mogła coś wiedzieć o Lublinie? (jw., przypis 1), z konkluzją najpełniej wyrażoną w stwierdzeniach: „Z punktu widzenia naukowego zaprezentowana wizja początków Lublina i jego późniejszej roli w systemie wewnątrzpaństwowych i międzynarodowych powiązań monarchii piastowskiej jawi się jako oparta na szeregu piętrowych hipotez, argumentów ex silentio i niemożliwych do zweryfikowania domysłów, co sprawia, że niepodobna przyjąc jej z aprobatą" oraz „Praca J. Chachaja, mimo wstępnych deklaracji, nie wytyczyła niestety nowych horyzontów dyskusji naukowej o dziejach średniowiecznego Lublina (o ile w ogóle jest to jeszcze możliwe, biorąc pod uwagę stopień zachowania materiału źródłowego [...]" (s. 299). Uzasadnieniem tak surowej oceny recenzowanego studium zajmowałem się szeroko w cytowanej rozprawie, stąd kwestii tej już tutaj nie rozwijam.

10 Zob. J. Chachaj, Jak nie nalešy zajmować sie historia (jw., przypis 1). 
wykazaniu niesłuszności, hiperkrytyczności lub zgoła trywialności mojej linii wnioskowania. Każdy, kto zada sobie trud wyczerpującego zapoznania się z oboma tymi głosami, uzupełniając je jeszcze obowiązkowo o lekturę wyjściowej pracy J. Chachaja, rychło zauważy, że poczet stosowanych przezeń argumentów merytorycznych nie uległ w Jego głosie polemicznym poszerzeniu w porównaniu do ich zasobu z ogłoszonej niedawno książki. Mogłoby się zatem zdawać, że dyskusja na jej temat nie wymaga już kontynuacji i dopowiedzeń. Po dogłębnej lekturze ostatniej wypowiedzi Szanownego Polemisty dochodzę jednak do zgoła przeciwnego wniosku, że pewne kwestie wymagają jeszcze wyjaśnienia, przedstawiona przezeń argumentacja krytycznej weryfikacji, a zarzuty poczynione pod adresem warsztatu recenzenckiego niżej podpisanego - rzeczowego odprawienia. Wydaje się, że - aby nie uronić niczego istotnego - najroztropniej będzie prowadzić ten dialog, kierując się kolejnością argumentów i uwag wybraną przez mojego Oponenta w jego ostatniej wypowied $z i^{11}$.

Godzi się rozpocząć od wyjaśnienia kilku kwestii ogólniejszej natury, pomieszczonych już w pierwszych ustępach polemiki J. Chachaja (s. 310-311). Nie bez słuszności zauważa On, że rozmiary ogłoszonego artykułu recenzyjnego są dość znaczne („Napisanie bardzo długiej recenzji było pretekstem do drobnych złośliwości” - s. 310, przyp. 2), ale twierdzi też zarazem, nie mając już przy tym racji, że jest to praktyka „,niespotykana” (,istotne skrócenie niespotykanie długiego artykułu recenzyjnego” - s. 310; „Niespotykany rozmiar recenzji [35 stron!] uniemożliwia szczegółowe odniesienie się do wszystkich uwag, bo odpowiedź musiałaby być zbliżona rozmiarami” - s. 311). Czy rzeczywiście mamy do czynienia z sytuacją nieznajdującą analogii? Bynajmniej, a za w pełni wystarczający dowód służą w tej materii chociażby wybrane i przywołane poniżej rozprawy recenzyjne, odnoszące się przeważnie do prac z zakresu wczesnego i dojrzałego średniowiecza ${ }^{12}$. Jakkolwiek truistycznie to nie zabrzmi, wszystko zależy więc od indy-

11 Odwołania do obydwu opublikowanych na łamach NP tekstów sygnalizuję, podając tak w tekście głównym, jak i w przypisach odpowiednią stronę (ewentualnie z przypisem) według reguły, że strony o numerach między 265 a 299 dotyczą mojego tekstu, a strony o numerach od 309 do 324 tekstu J. Chachaja.

12 Zob. np. R. Grodecki, Studya nad dziejami gospodarczemi Polski XII w., Kw. Hist. 29 (1915), nr 1, s. 257-294 (w związku z pracą K. Tymienie ckiego, Majętność ksiażeca w Zagości i pierwotne uposażenie klasztoru joannitón na tle osadnictwa dorzecza dolnej Nidy. Studyum z. dziejón gospodarczych XII w., Rozprawy Akademii Umiejętności, Wydział Historyczno-Filozoficzny [dalej: RAU whf], t. 55, Kraków 1912, s. 335-425); Z. Wojcie chow ski, Drieto o zwiazkach Polski z. Francja w wieku XII. Oswald Balzer o mistržn Wincentym, „Roczniki Historyczne” [dalej: Rocz. Hist.] 11 (1935), z. 2, s. 121-144 (także przedruk w: eiusdem, Hołd pruski i inne studia historyczne, Poznań 1946, s. 105-130) - dotyczy pracy O. Balzera, Studyum o Kadlubku, t. I-II, przygot. do druku H. Polaczkówna, Pisma Pośmiertne Oswalda Balzera, t. I-II, Lwów 1934-1935; H. Low miański, Kilka uwag krytycznych o „Poczatkach Polski”, Rocz. Hist. 18 (1949), s. 352-373 (artykuł rec. dotyczący pracy J. Widajewicza, Poczatki Polski, Wrocław 1948); G. Labuda, Uwagi o zjednoczeniu panstwa polskiego na przetomie XIII i XIV wieku, Kw. Hist. 62 (1955), nr 3, s. 125-149 (w związku z praca J. Baszkiewic za, Powstanie zjednoczonego państwa polskiego na przełomie 
widualnego przypadku recenzowanej publikacji i autonomicznego wyboru recenzenta. Nie sposób również zgodzić się z następną sugestia, jakoby ogłoszony tekst rozprawy recenzyjnej nie zasługiwał na miano „polemiki” z ustaleniami J. Chachaja („Nie jest także prawdą deklaracja złożona w przypisie pierwszym, że tekst stanowi polemikę z recenzowaną praca. Daremnym trudem jest szukanie w tekście jakichkolwiek jasnych deklaracji Autora na temat koncepcji i rozwoju organizacji kościelnej w najstarszym okresie dziejów Lublina. W najlepszym wypadku znajdziemy w niej jedynie opinie, że jakieś koncepcje są nie do przyjęcia” - s. 310, przyp. 3). Odpowiadając na tę uwagę, warto chyba przypomnieć fakt podstawowy, że jeżeli pomiędzy Autorem a recenzentem wystapiły fundamentalne rozbieżności na drodze egzegezy i interpretacji materiału źródłowego, a recenzent uzasadnił brak swojej zgody na przedstawione przez Autora propozycje i wnioski, przeciwstawiając im odpowiednie argumenty źródłowe i historiograficzne, to taka wypowiedź określa - mimo wszystkich zgłaszanych wątpliwości - jego stanowisko w toczącym się sporze i bez wątpienia wyczerpuje znamiona polemiki.

W pełni obstaję też - mimo sprzeciwu mojego Oponenta (s. 310, przyp. 3) - za dopuszczalnością nadania własnej rozprawie podtytułu Na marginesie koncepcji powstania i rozwoju organizacji kościelnej w Lublinie w XI-XIV wieku pióra Jacka Chachaja, ponieważ oprócz dominujących w niej zdecydowanie - czego nigdzie nie neguję - uwag stricte recenzyjnych, wskazuje ona, w jakich innych kierunkach badawczych opłaciłoby się snuć dalej podjęte dociekania z prawdopodobieństwem stanięcia mocną stopą na pewniejszym gruncie faktów, a także uzupełnia (na ile to było możliwe) niektóre szkice analitycznie, wskazując z niewykorzystanymi (lub nie w pełni wykorzystanymi) przez J. Chachaja przekazami źródłowymi w ręku, jakie racje stanowczo przeczą osiagniętym przez niego wynikom procedury poznawczej ${ }^{13}$. Nawet jednak gdyby rozprawa recenzyjna nie zawie-

\footnotetext{
XIII i XIV w., Warszawa 1954); idem, O stosunkach prawno-politycznych państwa polskiego z państwem niemieckim w X $i$ XI wieku, „Czasopismo Prawno-Historyczne” [dalej: CPH] 57 (2005), z. 1, s. 327 378 (w związku z praca J. So chackiego, Stosunki publiczno-prawne międry państwem polskim a cesarstwem ryymskim w latach 963-1102, Słupsk-Gdańsk 2003); J. Matu szew ski, O próbie nowej systematyki そ̧ródet bistorycznych, „Studia Metodologiczne” 4 (1968), s. 17-50 (w związku z rozprawą G. Labudy, Próba nowej systematyke i nowej interpretacii źródeł historycznych, „Studia Źródłoznawcze” [dalej: St. Źródł.] 1 (1957), s. 3-52); D.A. Sikorski, Kościót polski X-XII wieku we władsy monarchy i możnych. Uwagi na marginesie ksiażki J. Dobosza, Monarcha i możni wobec Kościoła w Polsce do poczatku XIII w., Poznań 2002, NP 100 (2003), s. 455-482; idem, Powstanie państwa Piastów w swietle najnowszych badan archeologii średniowiecznej, Rocz. Hist. 77 (2011), s. 205-228 (w związku z pracą M. Kary, Najstarsze państwo Piastón - rezultat przetomu czy kontynuacji? Studium archeologiczne, Poznań 2009); Sz. Wieczorek, Na manowcach. W zpriqqku z nowa kesiażka Jarostawa Wenty o Gallu Anonimie i jego „Kronice” J. Wen ta, Kronika tzp. Galla Anonima. Historyczne (monastyczne i genealogične) oraz geografiçne konteksty powstania, Torun 2011], Kw. Hist. 120 (2013), nr 3, s. 553-574. Lista innych, stosownych przykładów jest - co oczywiste - dużo bogatsza.
}

13 Godzi się zatem przypomnieć, że postulaty te objęły m.in.: a) pełniejsze niźli dotychczas podążenie śladem analizy komparatystycznej motywów wędrownych o założeniu jakiegoś miasta przez Gajusza Juliusza Cezara (s. 272-274), b) wprowadzenie do debaty nad Rychezą jako potencjalną założycielką Lublina fundamentalnego, a niewspomnianego i niezużytkowanego w ogóle przez J. Chachaja przekazu 
rała takich propozycji lub uzupełnień, to historiografia zna wiele przypadków, gdy tekst komentujący (lub nawet tylko omawiający) krytycznie i analitycznie daną publikację nosi podtytuł „na marginesie"

Koncentrując znaczną część uwag wstępnych na ustaleniu domniemanych przyczyn sformułowania przez piszącego te słowa obecnego tytułu artykułu recenzyjnego oraz okoliczności jego publikacji, co ma znaczenie co najwyżej trzeciorzędne, nie dostrzegł za to J. Chachaj, że zgłosiłem akces do większej liczby Jego propozycji aniżeli te, które sam skrzętnie wynotował (s. 310-311, przyp. 4), przyznając Mu również bez ogródek całkowitą rację w kwestii datacji początków kościoła św. Mikołaja na wzgórzu Czwartek, które - podobnie jak On sam - datuję dopiero na XIV w. Jest to już dziś niepodważalne ${ }^{15}$.

W największe zdumienie wprawia jednak inna wstępna deklaracja Szanownego Polemisty, który nie wyjaśniając w ogóle czytelnikowi, dlaczego przedstawiona kontrargumentacja Go nie przekonuje, apriorycznie zwolnił się z jakiejkolwiek analitycznej dyskusji, a do jej podjęcia w ogłoszonym kształcie skłonił go jedynie „całkowicie fałszywy

powstałego w jej najbliższym otoczeniu - tzw. Kroniki klasztoru w Brauweiler - i zestawienie jego osnowy narracyjnej z przekazami Galla Anonima i Mistrza Wincentego o wygnaniu Rychezy z Polski, który to wątek rozwinięty został analitycznie poprzez konfrontację stosownych „faktów źródłowych” (s. 275276), c) zwrócenie uwagi na niewymienioną przez Autora informację ze źródła archiwalnego, że mansjonaria w Lublinie (przy kaplicy zamkowej Świętej Trójcy) została ufundowana w 1497 r. przez Jana Olbrachta (s. 280, przyp. 31), a także d) propozycję, by do kwestionariusza pytań o okoliczności lokacji Lublina na prawie magdeburskim przez Władysława Łokietka włączyć kwestię, czy istniały jakieś analogie w rozwoju Lublina i innych miast lokowanych przez tegoż władcę, gdyż poza ich wymienieniem nie prowadzono jeszcze takich badań komparatystycznych (s. 295-296). Mogłyby one rzucić dodatkowe światło na politykę Łokietka wobec miast, zwłaszcza tych świeżo wówczas powstających, gdyż główne linie obranej przez niego i jego otoczenie polityki wobec znaczących ośrodków miejskich (takich jak Kraków czy Poznań) zostały już na ogół trafnie rozpoznane.

14 Por. tutaj K. S topka, Szkoly Małopolski średniowiecznej w świetle ostatniej monografii (na marginesie pracy Jana Rysia, „Szkolnictwo parafialne w miastach Matopolski w XV wieku”, Warsqawa 1995), „Przegląd Historyczny” [dalej: Przegl. Hist.] 87 (1996), z. 3, s. 615-630; Z. Pia now ski, Katedra czy katedry wawelskie w średniowieczu? Kilka uwag na marginesie ksiażki To mas za Węcławowicza, „Krakowski kościót katedralny w wiekach średnich. Funkecje i możliwości interpretacji” [Kraków 2005], „Acta Archeologica Waweliana” 3 (2006), s. 149151; Sz. Wi eczorek, „Omnibus omnia factus sum”. Na marginesie ksiażki T. Ja sińskiego, „O pochodzeniu Galla Anonima”, Kraków 2008, Avalon, ss. 132, Kw. Hist. 117 (2010), nr 4, s. 87-106. Znów jest to tylko wybór niektórych pozycji ze znacznie bogatszego zbioru.

15 Świadczą o tym odpowiednie słowa z mojej wypowiedzi: „Niewątpliwie najcenniejszą częścią $S_{z \text { Zkicu }}$ III jest esej pt. Jeszcze o poczqutkach kościoła św. Mikołaja (s. 190-197), który stanowi kolejny dowód, iż świątynia na Czwartku powstała zapewne w XIV w. i wszelkie wydłużanie na siłę jej dziejów jest zabiegiem sztucznym i nieuprawnionym”. Wywód ten, jakkolwiek lapidarny objętościowo, należy też uznać za najsilniej osadzony w podstawie źródłowej (s. 298). Pogląd, jakoby kościół ten miał metrykę jeszcze X-wieczną, a za jego fundatora mógł uchodzić Mieszko I, nie nadaje się do dyskusji, bowiem przynależy tylko do grupy „faktów historiograficznych”, nieznajdujących jakiegokolwiek zakotwiczenia ani w „faktach źródłowych”, ani w „faktach historycznych”. Prawdopodobną genezę tej lokalnej legendy lubelskiej, a także najstarsze dziejopisarskie i historiograficzne ślady jej funkcjonowania przekonująco naświetlił zaś właśnie J. Ch a chaj, Poczatki kościołów lubelskich, zwł. s. 47-59, 70-78 oraz ostatnio ide m, Lubelski kościót, s. 35-53, a zwł. 44-50. 
i niezgodny z prawdą obraz recenzowanej pracy" (s. 311), jaki ma się wyłaniać z mojego tekstu, którego styl i forma wypowiedzi dodatkowo rzekomo „zwalniają z obowiązku jakiejkolwiek polemiki z postawionymi przez Autora tezami i mogą raczej skłaniać do zachowania godnego milczenia" (s. 311). Obranie takiego stanowiska jest bez wattpienia najwygodniejsze; nie przybliża nas jednak ani o jotę do naświetlenia kwestii zasadniczej, a mianowicie czy sformułowana i ogłoszona przez J. Chachaja autorska wizja poczatków organizacji kościelnej i najdawniejszych wieków Lublina wytrzymuje napór metodycznej krytyki źródłowej i historiograficznej, czy też odwrotnie - przed tym naporem ustępuje.

Do udzielenia odpowiedzi na tę alternatywę przybliża nas analiza dalszych wywodów Autora, który na progu kolejnej części powziętej repliki podnosi, iż „niejasne sa już same przyczyny, dla których M. Kosonowski w ogóle podją się pracy nad artykułem recenzyjnym” (s. 311), a „wyjaśniając motywy kierujące nim przy podjęciu prac nad recenzja, wydaje się być co najmniej niekonsekwentny" (s. 312). Probierzem owej niekonsekwencji miałby być fakt, że domagam się odeń odrębnego uzasadnienia (s. 269), dlaczego uznał prawdopodobieństwo istnienia grodu lubelskiego już w pierwszej połowie XI w., ale nie formułuję już takiego postulatu pod adresem współtworzących tę debatę archeologów, którzy zdążyli w nieodległej przeszłości wystąić z analogicznymi sugestiami, co „nie budzi jego [tj. M.K.] zdziwienia" (s. 312). Nie zdołali oni jednak - i to jest w tym wypadku obserwacja najważniejsza - podnieść swoich przypuszczeń i hipotez do stopnia pewności, co logicznie implikuje konkluzję, że póki co nie istnieją żadne niepodważalne przesłanki, a tym bardziej dowody natury archeologicznej na rzecz tezy, iż przed druga połowa XII w. funkcjonował na terenie Lublina jakikolwiek gród już to plemienny, już to piastowski ${ }^{16}$. Oznacza to zarazem rzucenie w historyczny niebyt postulowanego

16 Najistotniejsze rozprawy i studia archeologiczne ogniskujące się wokół datacji początków Lublina zestawiłem obszernie w poprzednim artykule (s. 269-270, przyp. 6-7). Do wykazu tego dopisuję obecnie jeszcze ważny, zupełnie świeży artykuł M. Florka, Archeologiczne mity o poczatkach Lublina, [w:] Scientia nibil est, s. 463-475, którego autor kompetentnie podsumowuje meandry dotychczasowej debaty archeologicznej nad początkami lubelskiego ośrodka osadniczego, uwzględniając w swym przeglądzie kwestie domniemanych: a) grodu plemiennego na Wzgórzu Staromiejskim, b) grodu na wzgórzu Grodzisko (inaczej Kirkut) oraz c) teorii o translacji pierwotnego grodu piastowskiego na Grodzisku na Wzgórze Zamkowe w XII w. Ustosunkowując się do każdego z wyłuszczonych problemów badawczych, dochodzi zaś kolejno do takich konkluzji: ad a): „Reasumując, brak przekonujących argumentów w postaci wyników badań archeologicznych wskazujących na istnienie w wiekach VIII-X grodu plemiennego na Wzgórzu Staromiejskim” (s. 466), ad b): „W rzeczywistości dotychczasowe odkrycia pozwalają mówić jedynie w sposób pewny o istnieniu na tym terenie od VI/VII do IX, ewentualnie X w., osady o charakterze wiejskim, której pozostałością są odkryte tu półziemianki i jamy-piwniczki. Z całą pewnością nie natrafiono natomiast na jakiekolwiek relikty umocnień, które mogłyby być datowane na ten okres i stanowily dowód na istnienie grodu w okresie plemiennym. Wbrew opiniom A. Rozwałki brak jest również podstaw do datowania wału badanego przez S. Hoczyk w 1968 r. na pierwszą połowę wieku XI. Tym bardziej nie odkryto tu żadnych śladów mogących chociażby wskazywać na istnienie kościoła bądź kaplicy, jak również zabytków ruchomych, których charakter chociażby sugerował związek z osobami o wyższym statusie społecznym, z których obecnością powinniśmy się liczyć, gdyby istniał 
przez dawniejszą i nie tak dawną historiografię rzekomego plemienia „Lublinian”, co do których wypada powiedzieć tylko tyle, że wobec zupełnej niepewności istnienia lubelskiego ośrodka grodowego w dobie pierwszej monarchii piastowskiej wpisywanie ich w ówczesny krajobraz plemienny jest działaniem co najmniej przedwczesnym ${ }^{17}$. Milczą również na ten temat całkowicie źródła pisane, które dopiero od 1198 r. - poświadczając egzystencję archidiakona lubelskiego - dostarczają jakiegokolwiek materiału, na podstawie którego staje się możliwa naukowa rekonstrukcja pierwszych wieków dziejów Lublina ${ }^{18}$. Drugi raz, niemal równocześnie, pojawia się natomiast nazwa „Lublin”

tu gród - lokalne centrum władzy państwowej. Znikoma ilość zabytków, które mogą być datowane na XI w. (czy nawet w szerszych ramach chronologicznych, od XI do XIII w.), jak również brak obiektów nieruchomych z tego okresu (pomijając już brak tak datowanych fortyfikacji - podstawowego wyznacznika grodu) wskazuje, że nie tylko nie było tu w tym czasie grodu „państwowego”, lokalnego ośrodka władzy, ale również, że teren ten mógł być w ogóle niezasiedlony, lecz co najwyżej w jakiś sposób użytkowany, penetrowany przez mieszkańców okolicznych osad" (s. 468-469) oraz ad c): „Biorąc pod uwagę brak podstaw źródłowych do przyjmowania istnienia grodów na Wzgórzu Staromiejskim i wzgórzu Kirkut, jedynym pewnym grodem lubelskim, poświadczonym zarówno wynikami badań archeologicznych, jak i informacjami źródeł pisanych, pozostaje gród na Wzgórzu Zamkowym. W tej sytuacji [...] koncepcja translokacji grodu będącego głównym ośrodkiem lubelskiego zespołu osadniczego kolejno ze Wzgórza Staromiejskiego (gród plemienny) na Wzgórze Kirkut (gród „państwowy” z XI w.) i Wzgórze Zamkowe (gród kasztelański z XII-XIII w., przekształcony potem w zamek) musi być traktowana w kategoriach mitu archeologicznego" (s. 473); zob. też rozwinięcie tej samej argumentacji (głównie wobec grodu zamkowego) - idem, Zamek w Lublinie, [w:] Zamki Lubelszcsyzny w źródtach archeologicznych, red. E. Banasiewicz-Szykuła, Lublin 2015, s. 20-26, a zwł. 20-21, 24-25. Obserwacje M. Florka uwzględnia też w swoich najnowszych wypowiedziach J. Chachaj. Zob. idem, Poczattei lubelskiego ośrodka, s. 172, 186 (przyp. 63) oraz ide m, Znaczenie nowosiztnych przelkazón, s. 516 (przyp. 4).

17 Zob. w tej sprawie dawne mniemanie J. Widajewicza, Państwo Wiślan, Biblioteka Studium Słowiańskiego UJ, Kraków 1947, mapa przed tylną okładką na wklejce z zaznaczonym plemieniem Lublinian oraz zupełnie świeży i zbieżny z nim pogląd A. B uki, Archeologia Polski wožesnośrednioniecżnej, Warszawa 2005, s. 86 i n. Trzeźwą odprawę tej historiograficznej nomenklaturze dał (przy silnej dyskusyjności wielu pozostałych twierdzeń swojej rozprawy) P. Urbańczyk, Mieszko Pierwszy Tajemnicazy, Toruń 2012, s. 113.

18 Zob. Kodeks dyplomatyczny Małopolski, wyd. F. Piekosiński [dalej: KDMłp.], t. II, Kraków 1886, nr 376, s. 16-18: „Iohannem archidiaconum de Lubelnia recepimus” (wpis do tzw. Albumu klasztoru bożogrobców w Miechowie); por. tutaj od razu Z. Kozłowska-Budkowa, Repertorium polskich dokumentón doby piastowskiej, z. 1, Kraków 1937, nr 143, s. 132-134 oraz podstawowa rozprawa: W. Oblizajek, Najstarsze dokumenty bożogrobcón miechowskich (1198), St. Źródł. 24 (1979), s. 97-108. Informacją ta, jak również hipotetycznymi losami owego archidiakona, zajął się ostatnio J. Chach aj, Arcbidiakoni lubelscy do schytku XIV wieku, s. 170 (przyp. 6), 177-179 (tam też starsza literatura), a także id e m, Poczqatki lubelskiego ośrodka, s. 172, 195-196 (tutaj z osobna uwagą, iż zapis ten daje się filologicznie odczytać już to jako: „Jan, archidiakon lubelski”, już to jako „Jan z Lublina, archidiakon w ?”). Nie sądzę, aby drugi człon tej alternatywy mógł wylegitymować się na swą obronę czymś więcej niż logiczną dopuszczalnością takiego rozwiązania; faktura zapisów całego Albumu klasztoru miechowskiego jest pod tym względem nad wyraz przejrzysta. Cały ów wykaz składa się - jak zdążono już nieraz kompetentnie wyjaśnić - z dwóch zasadniczych kategorii osób: donatorów faktycznych, którzy dostali się do konfraterni bożogrobców drogą nadań i cesji majątkowych na rzecz ich miechowskiej wspólnoty oraz „,współbraci honorowych”, którzy znaleźli się w tym gronie z racji piastowanych uprawnień władzy publicznej, władzy episkopalnej lub innych godności urzędniczych w hierarchii elity świeckiej i duchownej. Zachowując tę podstawowa obserwację w pamięci, wystarczy następnie zweryfikować, według jakiej reguły pojawiają się w tym 
(w formie używanej dzisiaj) w Kronice Mistrza Wincentego Kadłubka w znanej opowieści o założeniu Lublina przez córkę Gajusza Juliusza Cezara - Julię, od której miałaby pochodzić nazwa „Iulin”, zmieniona później przez nałożnicę Lestka III na „Lublin”19.

wykazie dookreślenia osobowe „de...”. I tak kolejno: a) „Bolezlauus dux de Verzlaue et uxor eius et filijs suis Conrado et domino Ierozlauuo episcopo et duci (s.) Henrico” (KDMłp., nr 376, s. 16), b) „dominus Otto de Verbic dedit Dirscou” (ibidem, s. 17), c) „Iohannem archidiaconum de Lubelnia recepimus”, d) „Lodouicum de Craco recepimus” oraz e) „fratrem Christinum de Guenezne recepimus” (c-e, ibidem, s. 18). W przypadku Bolesława Wysokiego wraz z jego małżonką, synami Konradem, Jarosławem (biskupem wrocławskim) oraz najmłodszym Henrykiem dookreślenie „de Verzlaue” (Wrocław) ewidentnie kieruje zarówno w stronę manifestowanego przekonania o dziedzicznym posiadaniu księstwa wrocławskiego w linii Bolesława i jego potomnych (które to prawa manifestował Bolesław regularnie co najmniej od czasów powrotu z obczyzny w 1163 r. - zob. Magistri Vincentii dicti Kadtubek Cbronica Polonorum, ed. M. Plezia, Monumenta Poloniae Historica [dalej: MPH], ser. nova, t. XI, Cracoviae 1994, s. 125 (lib. III, cap. 30), jak i w stronę obszaru faktycznie sprawowanej książęcej władzy publicznej; może być zatem rozumiane dwojako. Wybitnie w charakterze własności dziedzicznej występuje Wierzbica przy imieniu Ottona, nadawcy Dzierżkówka (szerzej: S. Trawkowski, Otto ₹ Wieræ̌bicy, [w:] Polski Stownik Biograficzny, t. XXIV, Wrocław 1979, s. 635-637. Sprawę prawidłowego zaklasyfikowania archidiakona Jana rozstrzygają za to jednoznacznie trzy ostatnie wpisy (odnoszace się do niego samego oraz skądinąd nieznanych Ludwika z Krakowa i brata Krystyna z Gniezna). Jest nie do pomyślenia, aby dwaj ostatni sprawowali jakiekolwiek urzędy w swoich macierzystych ośrodkach, skoro wyjątkowo dbały o dokładność w tym względzie autor tych zapisów nic o tym nie wspomina. Zapisał on jednak godność archidiakońską przy imieniu Jana, który - nie będąc donatorem faktycznym na rzecz klasztoru, jak poucza nas forma „recepimus” („przyjęliśmy [Jana, archidiakona]”, zamiast „Iohannes, archidiaconus dedit...”) - musiał zostać ujęty w wykazie z tytułu piastowanej funkcji. Dlatego wprost narzuca się jako jedyne wyjaśnienie, że godność tę piastował w Lublinie; w przeciwnym razie autor odpowiedniej zapiski musiałby podać, gdzie indziej rozciagała się jego jurysdykcja.

19 Zob. Magistri Vincentii... Chronica Polonorum, ed. M. Plezia, s. 22-23 (lib. I, cap. 17). J. Chachaj utrzymuje (s. 320), że w ogłoszonym artykule recenzyjnym zaprzeczyłem samemu sobie, nie mogąc się zdecydować, która z tych wzmianek jest chronologicznie pierwsza. W rzeczywistości doszło do niezamierzonego (choć niedostrzeżonego $\mathrm{z}$ winy niżej podpisanego) błędu w trakcie korekty redakcyjnej tekstu, kiedy to we fragmencie: „Autor [tj. J. Chachaj-M.K.] przeoczył jednak bardzo ważną kwestię, a mianowicie fakt, że nazwa Lublin pojawia się po raz pierwszy właśnie w przekazie Mistrza Wincentego, który jest obecnie zgodnie datowany przez badaczy na przełom XII i XIII w.” (s. 277), słowo „nazwa” miało być - zgodnie z zamysłem - zastąpione przez określenie „forma” [zapisu tej nazwy]; to zaś miało prawo spowodować wrażenie chwiejności zajętego w tej materii stanowiska. Dla uniknięcia ewentualnych przyszłych nieporozumień wyjaśniam to więc od razu.

Za daleko idzie już jednak pogląd J. Chachaja, iż: „powoływanie się na zapis zawarty w przekazie Kadłubka jest o tyle zawodne, że najstarsze zachowane rękopisy kroniki, na których opierają się badacze, pochodza z XIV wieku” (s. 320). Aby zanegować poprawność lekcji „Lublin” jako oryginalnej, należałoby dostarczyć dowodu, że którykolwiek z najważniejszych rękopisów kroniki (o powszechnie używanych syglach: E [najstarszy, najbliższy oryginałowi z zachowanych], a także F, N1 oraz utracony bezpowrotnie I) zawiera inną lekcję niż „Lublin”. Tymczasem ostatnie, najlepsze wydanie krytyczne nie notuje żadnych odmian rękopiśmiennych w tym przypadku (Magistri Vincentii... Chronica Polonorum, ed. M. Plezia, s. 23); por. też ibidem, s. XII-XIV (wykaz wszystkich zachowanych rękopisów i ich filiacja), XXIV-XXVI (gdzie informacja, że wydawca oparł swą edycję na zachowującym najczęściej bardzo poprawne lekcje nazw osobowych rękopisie E, uzupełniając tekst o istotne odmianki z F, N1 i utraconego I - z wydania A. Bielowskiego [Ib] oraz korekt H. Dadejowej [Id]). Zob. tutaj M. Plezia, Podstawy do nowego mydania Kroniki Kadtubka, [w:] eiu s d em, Od Arystotelesa do „Ztotej legendy”, Warszawa 1958, s. 347-365 oraz idem, Tradycja rekopiśmienna Kroniki Kadtubka, [w:] Ars Historica. Prace z dżiejón Polski i powszechnych, Poznań 1976, s. 377-391. 
Wniosek, iż gród lubelski istniał przed drugą połową XII w., ma zatem li tylko charakter dedukcyjny, a wyprowadzenie go metodą indukcyjną z tworzywa źródeł archeologicznych oraz pisanych napotyka na przeszkodę nie do pokonania. Dlatego też mnogość głosów historiograficznych wskazujących na prawdopodobieństwo takiego rozwiązania - z których liczebnego bogactwa cały czas zdawałem i zdaję sobie sprawę - nie może zakryć ubóstwa, a raczej braku odpowiednich „faktów źródłowych”. To sprawę rozstrzyga. Krytykując hipotezę o XI-wiecznej metryce Lublina, nie akcentuję więc przesadnie - jak chce to widzieć Oponent (s. 312) - „rewolucyjności” samej tej hipotezy; stawiam natomiast konsekwentnie trudne do wyminięcia pytania o jej zasadność i weryfikowalność (s. 267-268, 269-270).

Deformacji uległo pod piórem J. Chachaja, nad czym ubolewam, także kolejne zastrzeżenie, które miałem sposobność skierować pod adresem Jego pracy, a które miałoby sprowadzać się do trywialnej w istocie konstatacji, iż zdecydowaną większość swoich dociekań poświęcił On XI i XII stuleciu, o których źródła nie przekazują zgoła żadnych danych. „Pierwszy z zarzutów postawionych przez Autora recenzji - pisze mój Adwersarz - dotyczy już samej kompozycji pracy. Po szczegółowym rozpisaniu spisu treści książki Recenzent dochodzi do wniosku, że »zarówno pod względem objętościowym, jak i doboru problematyki dominują rozważania nad XI i XII w., o których ze względu na niemalże całkowity brak materiału źródłowego niepodobna stwierdzić nic pewnego« (s. 267). Wniosek ten, do którego może dojść każdy, kto zada sobie trud zajrzenia do spisu treści, mając jednocześnie zupełnie elementarną wiedzę na temat dziejów Lublina, jest pierwszym z kilku »odkryć« Autora dotyczacych recenzowanej przez niego pracy. Udzielanie odpowiedzi na ten zarzut jest bezsensowne" (s. 312-313). Ale nie byłoby już z pewnością bezsensownym przywołanie właściwego rdzenia tego argumentu, który nie zagościł w wywodzie J. Chachaja ${ }^{20}$. Dla klarowności sytuacji należy

$20 \quad$ Przytoczony cytat z mojej wypowiedzi wyjęty został z kontekstu. Może warto go wobec tego przypomnieć: „Widać zatem, że zarówno pod względem objętościowym, jak i doboru problematyki dominują rozważania nad XI i XII w., o których ze względu na niemalże całkowity brak materiału źródłowego niepodobna stwierdzić nic pewnego. Trudno zatem uznać takie rozłożenie akcentów za najszczęśliwszy wybór. Wiedzę historyków mogą oczywiście wzbogacić odkrycia archeologiczne, jednak - co przyznaje sam Autor - „[...] mimo szumnych zapowiedzi, tego rodzaju odkryć wciąż brakuje« (s. 24). Rodzi się zatem podstawowe pytanie, na jakich źródłach została oparta zasadnicza część wywodów. Odpowiedź znajdujemy już w rozdziale I, gdy J. Chachaj sugeruje, aby: „Zwrócić baczniejszą uwagę na znane przekazy [pisane - M.K.], próbując poddać je nieco innej, niż się dotychczas przyjmuje, interpretacji (s. 24), bowiem »[...] pierwsze wieki historii Lublina wciąż nie są opisane przez historyków w sposób ostateczny« (s. 10). Rzeczywiście, do ustaleń poprzedników powinno się podejść krytycznie; nie zmienia to jednak zasadniczego faktu, że do dyskusji nie zostały w ostatnim czasie wprowadzone jakiekolwiek nowe świadectwa źródłowe, co stawia pod poważnym znakiem zapytania wszelkie próby reorientacji dotychczasowej optyki badawczej” (s. 267-268). Czy jest in aczej? Nb. ostatnie słowa z tego passusu napotkamy nieco dalej (s. 314), ale z wyraźnym błędem (zamiast „optyki badawczej” widnieje „problematyki badawczej”, co zupełnie zmienia sens wypowiedzi), opatrzone za to predykatem „absurdalności” w świetle stosowanej powszechnie metodologii naukowej. Poza 
wobec tego raz jeszcze postawić jedno i to samo pytanie: jeżeli mamy do czynienia ze studium naukowym (wprawdzie niemonograficznym, ale jednak opatrzonym bogatym aparatem erudycyjnym), to na jakiej wiarygodnej podstawie opiera się blisko 160 stron tekstu dotyczących XI-XII w., w przypadku których posiadamy tak skąpe, że prawie niezauważalne świadectwa źródłowe?

Na dowód, iż Jego praca bynajmniej nie musiała mieć określonych proporcji objętościowych kolejnych szkiców (narzucających się - przynajmniej w moim odczuciu przez specyfikę i szczupłość podstawy źródłowej dla kolejnych stuleci), przywołuje zaś J. Chachaj (s. 313) monumentalną syntezę analityczną Henryka Łowmiańskiego pt. Poczatki Polski, której - jak zauważa - tylko pokaźna część t. V (1973) oraz pewne partie t. VI (cz. 1-2, 1985) dotykaja „początków państwa polskiego” sensu stricto. Jeśli dobrze rozumiem, przykład ten miałby obrazować, że niejako wbrew obranemu tytułowi owej syntezy sygnalizowane w nim zagadnienie dochodziło do pierwszego szeregu rozważań H. Łowmiańskiego etapami, będąc poprzedzonym bardzo bogatym i obszernym preludium o etnogenezie Słowian i ich doświadczeniach w budowie zrębów własnej państwowości, a autor syntezy także nie ustrzegł się poruszania zagadnień, przy których egzegezie tryb oznajmujący obficie przeplata się z trybem przypuszczającym. Rozumowanie to jest jednak zawodne, ponieważ Henryk Łowmiański postawił sobie za cel najpierw: a) uchwycenie zalążków dwu wielkich procesów historycznych zespolonych ze sobą jak najściślej - tj. genezy państwowości polskiej oraz genezy narodowości polskiej - na tle dziejów Słowian w I tysiącleciu n.e. (t. I-V), następnie zaś b) śledzenie krystalizowania się narodowości polskiej przez pryzmat przemian politycznych, etnicznych, militarnych, społecznych, administracyjnych i ustrojowych w już istniejącym, choć ewoluującym regnum piastowskim od X/XI w. aż po XIV stulecie (t. VI) ${ }^{21}$. Na dłuższe zatrzymywanie się

prośbą o wierne cytowanie wypada mi więc w tym miejscu zaznaczyć, jakkolwiek truistycznie to nie zabrzmi, że każdy przekaz źródłowy niesie w sobie ograniczone pokłady informacji i mimo najbardziej usilnych starań z danych źródłowych o Lublinie w jego najdawniejszym etapie dziejów nie da się już obiektywnie wydobyć więcej, niż uczynili to nasi poprzednicy, którzy podeszli do tego zadania w lwiej części przypadków z pełnią kompetencji warsztatowej.

21 Zob. H. Low miański, Poczqtki Polski, t. I-V (z podtytułem Z driejów Stowian w I tysiacleciu n.e.), Warszawa 1963-1973 oraz t. VI, cz. 1-2 (ze znamienną zmiana podtytułu na Polityczne i społeczne procesy ksżtaltowania sie narodu do poczatku wieku XIV), Warszawa 1985. Trudno o bardziej przekonujący dowód na ciagłość założeń poznawczych i kwestionariusza pytań postawionego tej pomnikowej syntezie aniżeli słowa samego jej twórcy, który już w t. I (1963) nie pozostawił wątpliwości, iż: „W pojęciu początków Polski kryja się dwa zagadnienia: genezy państwa i genezy narodowości, pozostające ze sobą w ścisłym związku, gdyż państwo jest z reguły wytworem określonej grupy etnicznej i staje się z kolei istotnym czynnikiem przekształcenia się jego ludu w wyższą formę organizacyjna, czyli narodowość" (s. 7). W t. VI (cz. 1, 1985) nie tylko podtrzymał ten sąd, ale też doprecyzował, oddając swe stanowisko w słowach: „Oba rozpatrzone podstawowe problemy: genezy osadniczej oraz powstania państwa wśród przemian społecznych nie wyczerpują naszego zadania. W pojęciu "początków Polski« tkwi i wymaga omówienia jeszcze trzeci problem, sformułowany juz w pierwszym zdaniu tej pracy: kształtowania się narodu polskiego, pozostającego 
nad wydarzeniami dziejowymi, których nie oświetlają żadne źródła już to historycznej, już to archeologicznej, już to toponomastycznej proweniencji, H. Łowmiański nie zwykł sobie pozwalać. Wynika to z gruntownego zlustrowania jego twórczości, tak w okresie „wileńskim”, jak i „poznańskim”.

Obawiam się również, że J. Chachaj wyciągnął zbyt daleko idące wnioski z wyrażonego przeze mnie stanowiska w sprawie stawiania hipotez na niwie badań mediewistycznych, a zwłaszcza nad wczesnym średniowieczem (s. 314-315). Aby się o tym przekonać, wystarczy obrać za przewodnika Jego własną tezę, w myśl której: „w wielu miejscach recenzji natrafiamy na dowody nie tylko braku zrozumienia, ale też wręcz niechęci wobec wszelkich hipotez, których stawianie wydaje się dla niego [tj. M.K.] wręcz nieuprawnione przez historyka" (s. 314). Sytuacja wygląda zgoła odmiennie. Każdemu historykowi (także piszącemu te słowa) zdarza się stawiać hipotezy i nie są one bynajmniej „warsztatowym grzechem pierworodnym", ale nadużyciem jest już stawianie piętrowych hipotez, opieranie podstaw wywodu na argumentach ex silentio fontis oraz dedukcyjnych domysłach. Zabiegi tego typu, obojętnie w jakiej gałęzi literatury naukowej się pojawiaja (także w szkicach historycznych), nie przybliżają czytelnika do wyświetlenia danej problematyki, ponieważ jedną niewiadomą zastępują zespołem kolejnych i wystarczy jedno błędne założenie w takim ciagu, by runął on niczym domek z kart. Jeżeli zaś sam Autor przyznaje, że w Jego pracy (klasyfikowanej jako literatura naukowa) „hipotezy, często wielopiętrowe, czasami idące bardzo daleko, stawiane są niemal na każdej karcie" (s. 314-315), to nasuwa się pytanie, czy nie zbliżamy się w ten sposób do niebezpiecznej sytuacji, kiedy to osobiste przekonanie autora studium spełnia rolę strażnika prawdopodobieństwa pewnych rozwiązań? Przestrzegał przed takim obrotem sprawy już przed stu z górą laty Karol Potkański, a do identycznej uogólniającej, teoretycznopoznawczej konstatacji doszli również niezależnie Juliusz Bardach oraz Gerard Labuda ${ }^{22}$.

zresztą w najściślejszym z państwem związku. [...] Rządy sprawują dysponenci wiążący bez reszty swój los z powodzeniem państwa, źle się jednak dzieje z państwem, jeśli może liczyć jedynie na oddanych sobie dysponentów na kierowniczych stanowiskach - i tak bodaj nigdy nie bywa; $z$ reguły istnieje szerszy krag społeczny o zmiennym zasięgu, przywiązany do państwa, zaangażowany afirmatywnie w jego życie, wykraczający poza koło - i to bardzo znacznie - nosicieli i wykonawców władzy, gotowy do obrony państwa i do poświęceń na rzecz jego dobra. Ten szerszy kragg, oczywiście wraz z nosicielami władzy, rekrutujący się z reguły z grupy etnicznej firmującej państwo nazywamy narodem. Jego początek i kształtowanie się aż do zarysowania - w procesie jednoczenia państwowego na przełomie w. XIII i XIV - jego formy charakterystycznej dla następnych stuleci będzie przedmiotem badań przedstawionych w tym tomie" [podkr. moje M.K.] (s. 6).

22 Zob. K. Potkański, Kraków przed Piastami, RAU whf, t. 35, Kraków 1898, s. 101-102 (także przedruk, [w:] eiusdem, Lecbici, Polanie, Polska. Wybór pism, oprac., wstępem i posłowiami opatrzył G. Labu da, Warszawa 1965, s. 170-171). Wywód ten zasługuje na przytoczenie w dłuższym wyciagu: „Sa epoki w historii tak oddalone i tak mroczne, do których poznania zupełny brak źródeł, że nic o nich nie wiemy i wiedzieć nie możemy. Wtedy stwierdzamy wprost naszą niewiadomość; co najwyżej stawiamy a priori 
Jeżeli mój Oponent życzy sobie natomiast wiedzieć, ,jak w ogóle wyobraża sobie Autor recenzji uprawianie mediewistyki, prezentując posunięty do niechęci brak zrozumienia dla stawiania hipotez oraz co ma do powiedzenia na temat licznych w ostatnim czasie prac dotyczących początków państwa polskiego" (s. 315), to odsyłam do odpowiednich własnych rozpraw analitycznych, stanowiących przykłady wyznawanej przeze mnie metodologii, w której spostrzeżenia natury dedukcyjnej i hipotezy sytuują się jak najbardziej w granicach dopuszczalnego instrumentarium badawczego, ale zawsze ida rygorystycznie za metodą indukcyjnego wyprowadzania wniosków nawet z bardzo skąpej podstawy źródłowejej

W nieoczekiwanej szacie jawi się też kolejny zarzut J. Chachaja, który ustosunkowując się ponownie do kwestii uznawanego przezeń za prawdopodobny pobytu Gertrudy i Izjasława w Lublinie (i Kocku?) w połowie lat 70. XI w. (s. 315, 317-318), zamiast wykazać niesłuszność podanej kontrargumentacji źródłowej i wynikającej z niej chronologii kolejnych faktów, przenosi uwagę czytelnika na zupełnie drugorzędną w tym wypadku kwestię długości tego fragmentu ogłoszonego artykułu recenzyjnego (s. 288-292) w stosunku do jego pełnej objętości. Deliberując, dlaczego aż 40 proc. długości rozważań nad szkicem II z Jego książki poświęciłem tej tematyce, od razu znajduje gotowe wyjaśnienie,

pewne hipotezy, zapożyczając się - nieraz bardzo skutecznie - u innych ludów. [...] Taka półwiedza jest nieraz więcej kłopotliwa niż zupełna niewiadomość. Obudza naszą ciekawość, a nie zadowala jej, stawia wymagania naukowej metody - a nie może im zadość uczynić. Zamiast dowodów pewnych daje jedynie domysły i każe poprzestawać na prawdopodobieństwie i nim się jedynie zadowalać”; por. dalej J. Bardach, [rec.] W. Driewnlski, Postępy chrystianizacij i proces likwidacij pogaństwa w Polsce wczesnofeudalnej, Warszawa 1964, Przegl. Hist. 56 (1965), z. 3, s. 503: „Wiadomo dobrze, że wątła baza źródłowa dla wczesnego średniowiecza stwarza nieraz potrzebę ekstensywnej interpretacji, z której rodzą się nowe hipotezy i pomysły. O ile jednak z nowych hipotez, tj. tez podbudowanych odpowiednim dla aktualnego stanu badań uzasadnieniem, nie sposób zrezygnować, o tyle słabo kontrolowana profuzja nowych pomysłów może się okazać w konsekwencji zjawiskiem niebezpiecznym" oraz G. Labuda, O stosunkach prawno-politycznych, s. 376: „Takiego budowania hipotez opartego tylko na domysłach [...] nie mających oparcia ani w faktach historycznych, ani tym bardziej w faktach źródłowych, należy unikać w pracy naukowej”. Wszystkie te opinie zachowuja pełną aktualność dla każdego badacza.

23 Zob. tytułem przykładu: M. Ko so now ski, Gniezno cry Magdeburg? Ze studiów nad rywalizacja o prymat nad organizacja diecerjalna Kościoła katolickiego w Polsce w latach 30. XII wieku, NP 121 (2014), s. 5-56, a zwł. s. 16-54; idem, Legacja Gwalona z. Beauvais w Polsce w 1103 roku, Rocz. Hist. 81 (2015), s. 57-85; idem, Dokumenty księznej Salomei i ksiecia Miesžka Starego dla klasztoru Benedyktynów w Mogilnie ₹ XVII-wiecznego kopiariusza Archiwnm Krakowskiej Kapituly Katedralnej. Studium krytyczne i edycja tekstów, [w:] Signa. Studia i sqkice z nauk pomocnicaych historii. Prace dedykowane Profesorowi Zenonowi Piechowi w sześćdziesiata rocznice urodzin, red. A. Marzec, M. Starzyński, Kraków 2014, s. 29-58; idem, Studium krytycžne nad dokumentem legata Reginalda (Rajnalda). Praycryynek do dyplomatyki polskiej XII wieku, Przegl. Hist. 108 (2017), z. 1, s. 2966. Dochodzą do tego zaopatrzone w aparat erudycyjny obszerniejsze oglądy recenzyjne ukazujących się na bieżąco rozpraw z zakresu historii politycznej X-XII w. - zob. idem, O ustawie sukcesyjnej Bolesława Kryywoustego w kontrowersyjnym ośnietteniu. [W zwiazku zpraca Jacka Osinskiego, „Statut Bolestawa Kryywoustego", Wydawnictwo Avalon, Krakón 2014, ss. 271 + 5 tablic], CPH 67 (2015), z. 2, s. 237-269; ide m, O najnowsyym historiograficznym portrecie Wtadystawa Hermana [W zwiqzku z.praca Adama Krawca, „Król bez korony. Wtadystaw Herman, ksiqzie Polski”, Wydawnictwo Naukowe PWN, Warszawa 2014, ss. 303+ 1 nlb.], „Studia Historyczne” 58 (2015, wyd. 2017), z. 4, s. 539-564. 
że ,jedyną odpowiedzią na to pytanie wydaje się fakt, że była to okazja do popisów elokwencji i umieszczenia w tekście rozbudowanych przypisów zawierających w największej części niczemu niesłużące obszerne łacińskie cytaty” (s. 315). Można zrezygnować w dyskusji z argumentacji źródłowej (nawet w przekładzie polskim), ale niedaleko się na tej drodze zajdzie, zwłaszcza gdy są to świadectwa bliskie chronologicznie opisywanym wydarzeniom i - co nie mniej istotne - dobrze poinformowane o ich biegu. Przeciwko propozycji J. Chachaja lokującej wygnaną z Kijowa parę książęcą w Lublinie przemawia bowiem nie tylko całkowite milczenie wszelkich przekazów źródłowych (co już ma dużą wagę), ale także połączone świadectwa pierwszorzędnych w swej osnowie informacyjnej kronik: najpierw Lamperta z Hersfeldu, dalej zaś dorzucającej do niej własne wiadomości ruskiej Powieści minionych lat.

Wbrew zapewnieniom Szanownego Polemisty (s. 317-318) nie warto rezygnować z przypomnienia faktów zamykających się w obrębie pierwszej połowy 1075 r. (pobyt Izjasława na dworze Henryka IV w Moguncji na początku 1075 r., poselstwo w obronie jego praw do tronu w Kijowie pod przewodem Burcharda - prepozyta z Trewiru, oddanie Izjasława wraz z żoną pod kuratelę margrabiego Miśni Dediego aż do lipca lub października 1075 r.); należy je jednakowoż zestawić od razu z zanotowaną w Powieści minionych lat pod rokiem 6584 [tj. 1076] wyprawą Włodzimierza Wsiewołodowicza i Olega Światosławowicza wespół z Bolesławem Szczodrym na Czechy ${ }^{24}$. Nie trzeba tłumaczyć, że zapiska o tej wyprawie, której wiarygodność i datację petryfikuje dodatkowo tzw.

$24 \quad$ Wyczerpujący drogowskaz źródłowy i historiograficzny dla zainteresowanych losami wygnanych z Kijowa Gertrudy Piastówny i Izjasława Jarosławowicza w latach 1074-1077 ustawił ostatnio N. Delestowicz, Okoliczności pobytu Izjastawa Jarostawowicza na dworze króla niemieckiego Henryka IV w latach 1074-1077, [w:] Colloquia Russica. Seria I, nr 4: Rurikids in Dynastic Relations: Politics, Customs, Culture, Religion (10 th-16 $6^{\text {th }}$ Century), ed. by V. Nagirnyj, Kraków 2014, s. 61-72 oraz w poszerzonej wersji idem, Bolestaw II S zczodry, Kraków 2016, s. 189-207. Moje ustalenia (s. 288-289, przyp. 47-53) idą zasadniczo w zbieżnym kierunku, zwłaszcza gdy chodzi o kwestię chronologii pobytu Gertrudy i Izjasława w Niemczech pod kuratela margrabiego miśnieńskiego Dediego, który to pobyt musiał trwać co najmniej do lipca/sierpnia 1075 r., a być może nawet października tego roku (por. N. Delestowicz, Bolestaw II Szczodry, s. 190-191 z przyp. 8, s. 196-197 z przyp. 30). Tymczasem J. Chachaj, Lublin - miasto Rychesy?, s. 113 (przyp. 123), zreferowawszy stanowisko T. Michałowskiej w tej sprawie (zob. eadem, Ego Gertruda. Studium historycznoliterackie, Warszawa 2001, s. 156-161 oraz przypisy na s. 235-237), stwierdza, iż: „Bez wątpienia zatem już wiosną 1075 roku zaistniały warunki, w których rodzina Gertrudy mogła udać się z Miśni nie nad Ren, lecz nad Wisłę". Bez wątpienia? Z wywodów T. Michałowskiej wynika coś zgoła przeciwnego, a zbieżnego z tym, jak widzą ostatnio chronologię rozwoju tych wydarzeń N. Delestowicz oraz piszący te słowa. Posłuchajmy więc jej stanowiska: „Wiemy od Lamberta, że na początku stycznia 1075 r. król Henryk IV zlecił Iziasławowi, aby pozostając pod opieką margrabiego Dediego, czekał na powrót z Kijowa poselstwa Burcharda. Ten sam kronikarz odnotował następnie, że królewscy wysłańcy przybyli z Rusi (do Wormacji, gdzie przebywał wówczas niemiecki władca) w końcu lipca lub sierpniu tegoż roku. Możemy więc przyjąć, że Iziasław oraz Gertruda - jeśli zastosowali się do życzenia królewskiego - od zimy do późnego lata 1075 r. przebywali na dworze Dedich [podkreślenie moje - M.K.]” (s. 161). Watpliwości wobec propozycji J. Chachaja mają więc prawo się rodzić, stąd za uzasadnione uważam ich zgłoszenie (s. 288-289). 
Pouczৃenie Wtodżimierza Monomacha, ewidentnie naprowadza na fakt, że pomiędzy Bolesławem a panującym w Kijowie Światosławem istniał aż do śmierci tego ostatniego (27 XII 1076 r.) sojusz polityczno-wojskowy. Rzuca się więc ostatecznie w oczy, że wobec ewidentnego trwania takiego sojuszu aż do końca 1076 r. nie ma i nie mogło być miejsca na wspieranie przez Bolesława racji Izjasława w jego zabiegach o ponowne wyniesienie na tron wielkoksiążęcy w Kijowie, a domniemane osadzenie go tymczasowo w pogranicznym Lublinie (przyjmując nawet na wyrost za udowodnione, że gród już w tym czasie istniał), byłoby krokiem nad wyraz ryzykownym i mogacym w praktyce wystawić na szwank trwałość przymierza Bolesławowego ze Światosławem Jarosławowiczem ${ }^{25}$.

Wyprowadzonego z wymienionych wyżej źródeł obrazu wygnańczych losów Gertrudy i Izjasława w żadnej mierze nie są natomiast w stanie zmienić zdecydowanie późniejsze przekazy polskiej proweniencji, na których zbyt powierzchowną egzegezę (lub nawet ich zlekceważenie) z mojej strony zwrócił uwagę J. Chachaj (s. 316). Wychodząc naprzeciw Jego oczekiwaniom, winienem zatem poddać baczniejszym obserwacjom również: a) fragment najstarszego inwentarza majątkowego biskupstwa płockiego (zachowany w XIV-wiecznym rękopisie oraz wciagnięty do podfałszowanego dokumentu Konrada Mazowieckiego z niemożliwą datą 1203$)^{26}$ oraz b) jeszcze późniejszy przekaz

Przypominam też raz jeszcze jednoznaczne świadectwo Powieści minionych lat pod rokiem 1076: „В $\Lambda$ bтo 6584. Ходи Володимеръ, сынъ Всеволожь, и Олегъ, сынъ Святослав ьь, Аяхомъ в помочь на чехы. Сего же $\Lambda$ бта преставися Святославъ, сынъ Ярославль, мЂсяца Аекабря 27, от рђзанья желве, и положенъ Черниговђ у святаго Спаса. И съде по немь Всеволодъ на столь, мъсяца генваря", в 1 ден (cyt. wg Повесть временных лет, Ч. 1, подготовка текста А.С. Аихачева, перевоА А.С. Аихачева, Б.А. Поманова, Москва- Аенинград 1950, s. 131-132) oraz wtórujący mu przekaz Pouczenia Wtodzimierza Monomacha: „та посла мА С Тосслав ьь в $\Lambda$ ахы. ходь за ГАоговы. до Чешьскаго $\Lambda$ Ђса. Ходивъ в земли ихъ. Ӓ.мЂсАци" (Полное собрание русских летописей, t. 1: Ааврентввевская летоопись, wyd. 2, АенинграА 1926, kol. 247). Próba emendowania tej daty na 1075 r. przez V.A. Kučkina, zaakceptowana początkowo przez A. Barciak a, Przekaz latopisu ruskiego o myprawie polsko-ruskiej na Cz̨echy w roku 1075, „Śląskie Studia Historyczne” 2 (1977), s. 29-35 oraz Z. Kozłowską-Budkowa, W sprawie relacii Mistrza Wincentego „Chronica Polonorum” ksiega II c. 18 i 20, [w:] Mente et litteris. O kulturze i spoteczeństwie wiekón średnich [Księga Pamiątkowa dla B. Kürbis], Poznań 1984, s. 123, nie są obecnie przyjmowane w charakterze pewników, a wręcz powraca z całą mocą tradycyjna datacja na $1076 \mathrm{r}$. - por. A. Kijas, Wtodzimierz. Monomach, [w:] Stownik starosytności stowianskich [dalej: SSS], t. VI, red. G. Labuda, Z. Stieber, Wrocław-Warszawa-Kraków-Gdańsk 1977, s. 534-535; N. Delestowicz, Bolestaw II Szczodry, s. 161-162 (przyp. 77-81).

25 Przeciwko hipotezie J. Chachaja oświadczył się przeto N. Deles towicz, Bolestaw II, s. 115 (przyp. 75), opatrując ją znamiennym komentarzem: „Jednakże należy zauważyć, że hipotetyczne przypuszczenia poczynione przez autora nie mają racji bytu. Na ich poparcie brak wzmianek źródłowych. Podkreślić należy, że najprawdopodobniej nie uda się określić miejsca pobytu Izjasława wraz z rodziną w Polsce. Hipotetycznie mógł rezydować w jakimkolwiek grodzie, a nic prócz autorskiego domysłu nie przemawia za Lublinem".

26 Zob. najpierw Castellaniae Ecclesiae Plocensis, Telonea episcopi Plocensis, Villae capituli Plocensis, wyd. W. Kętrzyński, [w:] MPH, t. V, Lwów 1888, s. 434: „Item in Pogost circa Lublin Cvotsko cum ecclesia et foro et taberna et viliis ei pertinentibus et cum omnibus solucionibus earumdem villarum" (wersja inwentarza z XIV-wiecznego rękopisu), potem zaś Codex diplomaticus et commemorationum Masoviae 
Jana Długosza, który in suo Libri beneficiorum wiąże okoliczności nadania tzw. klucza kockiego biskupstwu płockiemu z donacją bliżej nieznanego księcia włoskiego, który nie został przezeń w żaden sposób osadzony w czasie i niepodobna powiązać go z jakimkolwiek aktorem procesu dziejowego ${ }^{27}$.

Każdy, kto zapozna się bliżej z tymi świadectwami źródłowymi, musi dostrzec najpierw fakt podstawowy, że żadne z nich bynajmniej nie poczuwa się do jakiejkolwiek łączności z losami Gertrudy i Izjasława i trzeba mieć w sobie wiele badawczej odwagi, aby podjać takie zabiegi wokół ich interpretacji. Ponad wszelką wątpliwość nie wskazuje na nią określenie „Item in Pogost circa Lublin Cvotsko [lub Kocsko] cum ecclesia et foro et taberna et viliis ei pertinentibus et cum omnibus solucionibus earumdem villarum" zawarte w inwentarzu majątkowym biskupstwa płockiego, albowiem przekaz ten dostarcza w zajmującej nas materii tylko i wyłącznie prostej informacji, że w okolicach Lublina leżały dobra biskupstwa płockiego w postaci samego Kocka wraz z kościołem, karczmą, przynależnymi wsiami itd. Te dobra wymagały wszakże ze względów pragmatycznych dokładniejszej lokalizacji, i takiej też roli należy dopatrywać się w określeniu

generalis, wyd. J.K. Kochanowski, t. I, Warszawa 1919, nr 301 (podfałszowany dokument Konrada), s. 344 - ,item in Pogost [sic!] circa lvblyn [sic! - M.K.] Kocsko cum Eclesia et foro et tawerna et cum viliis et pertinenciis".

27 Zob. Joannis Dlugosz... Liber beneficiorum dioecesis Cracoviensis, [ed. L. Lętow ski], t. I (Ioannis Dlugossii Opera omnia, t. VII), Cracoviae 1863, s. 629-630. Aby zorientować się w świecącej z daleka nikłej wartości tego przekazu, niezaopatrzonego w jakiekolwiek szczegóły faktograficzne, należy koniecznie przywołać go w całości: „Dum siquidem sub regimine et principatu... Poloniae... princeps et regulus Italicae orae, vel propter aliquod scelus patratum, vel ob livorem et invidiam, uti ipse asserere solebat, a suis pulsus et exiliatus foret, non habens ubi tutum posset agere incolatum, ad regnum Poloniae pervenisset, ubi clementius quam sperebat a... principe Poloniae exceptus et benigne tractatus et habitus est, qui cum ad suam patriam propiusque penates regredi non auderet, veritus, ne proprii quicquam gravius in eum consulerent, perpetuam sibi apud Poloniae regnum elegit sedem; cuius calamitati princeps preafatus Poloniae... compassus, sibi oppidum Koczsko cum quinque villis, videlicet Thalczyn, Gorka, Pozarow, Tharkawycza, Luszawa in perpetuam contulit possesionem et haereditatem, privilegians illum praerogativa speciali, ut bona praefata, si absque prole decederet, posset cuicunque ecclesiae in elemosynam, aut cuicunque amico vel familiari in proprietatem et donationem perpetuo conferre. Hic itaque... Italicus princeps, cum universum tempus dierum suorum apud Poloniae regnum in omni honestate et virtute vitam traducens, exegisset, indignum ratus iugo coniugali se subicere, ad perpetuam continentiam animum adiicens, orbus et absque liberis diem obiit. Cernens itaque sibi supremum imminere diem, bona sua praefata, Koczsko videlicet oppidum, et quinque villas praefatas cathedrali Ploczensi ecclesiae, apud quam sibi vivens elegerat supulturam, perpetua donatione in elemosynam contulit, donavit et inscripsit; functusque vita, in eadem Ploczensi cathedrali ecclesia sepultus cum pietate requiescit" (wielokropki w cytowanym passusie pochodzą od wydawcy). Wprost rzuca się w oczy, że mamy tu do czynienia z sytuacja, gdy znany ze swej wzorowej skrupulatności w zbieraniu danych o źródłach uposażenia dóbr biskupstwa krakowskiego Jan Długosz nie umiał odnaleźć jakiegokolwiek dokumentu, który rozjaśniłby mu okoliczności, w jakich biskupstwo płockie weszło w posiadanie Kocka oraz otaczających go wsi. Gdyby dostępny był mu jakikolwiek dyplom, niechybnie podałby konkretnie osobę darczyńcy i datę. Skoro takowych danych nie podaje, musiał oprzeć się na jakiejś lokalnej tradycji (zapewne z kręgu katedry płockiej, skoro ów „książę włoski” miał zostać w niej pochowany). Na ile jednak oddał tę tradycję wiernie, a na ile wzbogacił własną fantazją, to już zupełnie inna sprawa. 
„in pogost”, co wskazuje raczej na określenie jakiejś krainy geograficznej, w której obrębie leżał Kock z przyległościami. Jej nazwa mogłaby - etymologicznie patrząc - mieć zbliżony źródłosłów do dzisiejszego Polesia ${ }^{28}$. Nie wolno też przechodzić do porządku dziennego nad faktem, że wszyscy kompetentni badacze (za wyjątkiem jednego Wojciecha Kętrzyńskiego) zgadzają się co do tego, że inwentarz - obojętnie, które z przechowujących go dziś źródeł obierzemy za przewodnika - nie jest w znanym nam obecnie brzmieniu i fakturze źródłem współczesnym fundacji biskupstwa płockiego w połowie lat 70. XI stulecia; wchłonął on natomiast bez cienia wątpliwości starsze zapisy donacyjne, ciagnące się długim pasmem od XI do XIII w., o których zaistnieniu przetrwała pamięć katalizowana stosownymi zapiskami lub które zachowały swoją aktualność do XIII w., kiedy to najwcześniej za pontyfikatu Guntera (przed 1227-1232), a może dopiero w XIV w., mógł zostać spisany w swej aktualnej szacie stylistycznej znany dziś inwen$\operatorname{tarz}^{29}$. Bez względu wszakże na to, czy oświadczymy się za XIII- czy XIV-wieczną me-

28 Tutaj należy poczynić od razu obserwację zasadnicza, iż w świetle poglądów J. Chachaja nazwa ta została zapożyczona do źródła polskiego z języka staroruskiego, gdzie pod takim terminem rzeczywiście znane są osady stojące na szczeblu rozwoju pomiędzy wsią (siołem) a ośrodkiem grodowym, specjalizujące się często w wymianie handlowej lub też jednostki administracyjne zarządu państwem w dobie staroruskiej. Zob. w tej sprawie H. Łow miański, Pocz̨atki Polski, t. III (1967), s. 393-401 oraz A. Poppe, Driedzice na Rusi, Kw. Hist. 74 (1967), nr 1, s. 11-17. Nie czuję się przekonany co do słuszności takiego stanowiska, i to z dwóch powodów. Po pierwsze, inwentarz majątkowy biskupstwa płockiego operuje stale nazewnictwem łacińskim lub średniowiecznymi polskimi nazwami własnymi, dlaczegoż by więc ten jeden raz miał odwoływać się do obcej, ruskiej nomenklatury? Po drugie, z samej stylizacji zapisu wynika, iż ani Lublin, ani tym bardziej Kock nie mogły być centralnymi ośrodkami pogostu (gdyby rozumieć go w znaczeniu jednostki administracyjnej), gdyż Lublin leżał poza jego granicami, a autor pisze wyraźnie o Kocku leżącym w granicach pogostu, a nie pogoście kockim. Stąd też po dłuższym zastanowieniu wnoszę, iż pogost jest w rozpatrywanym wypadku nazwą geograficzna (typu Polesie, Podlasie), na co może naprowadzać sama etymologia słowa, którego rdzeń gost' (,gozd') jest wspólnym wielu językom słowiańskim określeniem, „gęstego lasu”. Zob. A. Br ückner, Stownik etymologiczny języka polskiego, t. I, Kraków 1927, s. 166 („,gwozd, gozd” = „las”); F. Sław ski, Stownik etymologiczny jezylka polskiego, t. I, Kraków 1952-1956, s. 329-330 (gozd - do XV w. 'gęsty las, pustkowie') oraz I. Kaczor, Kult drzew w tradycji mitologicznej i religijnej staros̀ytnych Greków $i$ Raymian, Acta Universitatis Lodziensis. Folia Litteraria Polonica, t. 3, Łódź 2001, s. 7-8. Nawet jednak gdyby forma „Pogost” była pożyczką z języka staroruskiego, czego apriorycznie wykluczyć się nie da, nie oznacza to jeszcze, że uzasadnione jest szukanie jej genezy bez osobnego dowodu w tak odległym czasie jak 2. poł. XI w. W przeciwnym razie grozi nam petitio principii.

29 Pogląd, iż zasadniczy rdzeń tego zestawienia został ułożony i spisany jeszcze w dobie fundacji biskupstwa płockiego w latach 70. XI w., wprowadził do dyskusji jego odkrywca - W. Kętrzyński dając wyraz swemu przekonaniu kilkakrotnie - zob. idem, Założenie i myposażenie biskupstwa plockiego, „Przewodnik Naukowy i Literacki” 14 (1886), s. 385-392, 481-488, zwł. s. 386-387 oraz w uwagach wstępnych do: Castellaniae Ecclesiae Plocensis..., s. 419-433, a zwł. 425 z konkluzja: „Odnosimy ułożenie wspomnianego pisma [tj. inwentarza w wersji z rękopisu XIV-wiecznego - M.K.], jak nas sama treść poucza, do czasów fundacyi biskupstwa płockiego, która niewątpliwie miała miejsce w XI wieku”. Pogląd ten nieodwracalnie nadwątlił jednak już B. Ulanowski, O uposażeniu biskupstwa płockiego, RAU whf, t. 21, Kraków 1888, s. 35-37, przenosząc moment powstania tego źródła na lata sprawowania posługi biskupiej w Płocku przez Guntera i całkowicie słusznie wiążąc go z okresem wzmożonych najazdów łupieżczych Jaćwingów i Prusów na ziemię mazowiecką w tym okresie. Pogląd ten zasadniczo 
tryką tego wykazu, jedno nie ulegało i nie ulega wątpliwości - passus o Lublinie, Kocku i Pogoście nie może być uważany za oddający XI-wieczne realia własnościowe biskupstwa płockiego, bowiem świeci niczym fałszywa perła w kolii w zupełnie przejrzyście skonstruowanym opisie posiadłości tworzących cztery „kasztelanie” prawobrzeżnego Mazowsza, skupione wokół grodów w Pułtusku, Brańsku, Broku i Święcku (po opisie posiadłości z „kasztelanii” brańskiej, a przed brocką, co burzy reguły opisu nawet ze względów geograficznych) ${ }^{30}$.

Jeszcze sroższy werdykt należy wydać na przekaz Jana Długosza, bowiem opowieść ta (wyjątkowo mglista, nieznająca żadnych konkretów faktograficznych poza spisem dóbr tworzących tzw. klucz kocki) nie została ewidentnie oparta na żadnym źródle pisanym i może - co najwyżej - pochodzić z jakiejś nieuchwytnej dziś tradycji płockiej. Aby móc uczynić z owej opowieści jakikolwiek użytek, należałoby najpierw dociec, na jakim konkretnie starszym źródle mogłaby być osnuta. Do momentu wskazania takiego przekazu dyskusja nad nią w kontekście losów wygnanej z Kijowa pary książęcej nie

utrzymał H. Łow miański, Poczqatki Polski, t. VI, cz. 1 (1985), s. 355-361, tutaj s. 357-358, zanegował zaś K. Myślińs ki, Najstarsza miejska bistoria Lubelszczyzny w świetle dokumentu Konrada Mazowieckiego z roku około 1239, [w:] Studia Historyczne. Ksiega jubileuszowa z okazji 70. rocznicy urodzin prof. dr. Stanisława Arnolda, Warszawa 1965, s. 288-300, a zwł. s. 290-294, 298-300, dopatrując się w inwentarzu dzieła o dopiero XIV-wiecznej metryce, które miałoby też posłużyć do podrobienia dokumentu Konrada Mazowieckiego w połowie XV w. (por. tutaj aprobatywną rec. J. Szy mańskiego: „Rocznik Lubelski” 8 (1965), s. 263264). Zaledwie musnął to zagadnienie Z. Sułows ki, Poczqtki organizacïi kościelnej na Mazowszu, „Studia Płockie” 3 (1975), s. 42: „Uposażenie biskupa płockiego stanowiły zapewne dziesięciny z obszaru całej diecezji, pobierane dotychczas przez metropolitę. Nadto otrzymał nowy biskup pewne dobra, znane nam jedynie z późniejszego wykazu. Trzon ich stanowiły kasztelanie na wschodzie: Pułtusk, Brańsk (dziś Brańszczyk), Brok i Swięck"; na pytanie, kiedy konkretniej powstała obecna redakcja tego spisu, niewiele można się tutaj doczytać. Za pierwszą połową XIII w. optuje ostatnio ks. W. Graczyk, Organizacja kościelna na Mazowszu do potowy XII wieku, [w:] Kościót, kultura, polityka w państwie pierwszych Piastów, pod red. W. Graczyka et al., Warszawa-Ciechanów 2016, s. 234-235. Godzi się wreszcie przypomnieć porządkująca glossę marginalną G. Labudy, Kto był założycielem biskupstwa płockiego?, „Notatki Płockie” 1989, nr 1, s. 9-11, iż: „Nie należy też wątpić, że biskup [płocki - M.K.] polecił od razu założyć inwentarz, tj. księgę lub sporządzić kartę, na której od razu zapisano wszystkie otrzymane wówczas, jak i później darowizny, świadczenia i przywileje skarbowe. O istnieniu takiego [a nie: tego! M.K.] inwentarza dowiadujemy się z dwu niezależnych źródeł, mianowicie z dokumentu księcia Konrada, noszącego datę 1203 roku, lecz prawdopodobnie sporządzonego około roku 1239, oraz z osobnej księgi inwentarzowej, pochodzącej z XV wieku, w których można, co prawda z pewnym trudem, wyłuskać pierwotne XI-wieczne uposażenie biskupstwa płockiego” [podkreśl. moje - M.K.]. Godzi się jedynie dodać, że ewolucja uposażenia majątkowego biskupstwa płockiego w całej rozciąłości wieków średnich dojrzała już wyraźnie do nowej, analitycznej rozprawy.

30 Trafnie wydobył reguły tego opisu H. Łowmiański, Poczqatki Polski, t. VI, cz. 1 (1985), s. 358, opatrując swe uwagi równie trafnym komentarzem: „Niektóre z wtrętów merytorycznych wskazał expressis verbis tekst inwentarza; do ich rzędu należy przede wszystkim wzmianka o Pogoście pod Lublinem oraz o Kocku. Jest jasne, że Bolesław II nie miał powodu, ażeby wyposażać w dobra małopolskie biskupstwo, które w tym momencie nie miało możności rozwijać w tej dzielnicy aktywności misyjnej, a samo musiało korzystać z pomocy benedyktynów mogileńskich. Nadanie dóbr w ziemi sandomierskiej przypisać należy zapewne Kazimierzowi Sprawiedliwemu mającemu na celu uzyskanie poparcia na Mazowszu ze strony biskupa płockiego". 
znajduje punktu wyjścia, zwłaszcza że w cytowanej wyżej (przyp. 27) narracji Długosza ów nieznany i bezdzietny „książę włoski” miał zostać pochowany w katedrze płockiej, co było konsekwencją decyzji podjętej przezeń za życia. Wyklucza to już na starcie wszelkie podobieństwa z Izjasławem.

Pozostając jeszcze przez chwilę w kręgu postulowanych przez J. Chachaja dopowiedzeń i zasygnalizowanych usterek (s. 316), spieszę natomiast przyznać Mu rację, że istotnie do językoznawczych ustaleń Stefana Warchoła i Stanisława Rosponda (ogniskujących się wokół prób etymologizacji nazwy Lublin - zob. s. 277, przyp. 26) można było i godziło się dodać konkurencyjne wobec nich stanowisko Kazimierza Myślińskiego, co uszło mojej uwadze przy korekcie redakcyjnej tekstu, choć głos ten był i jest mi znany $^{31}$. Mija się już jednak zasadniczo z treścią wypowiedzi recenzyjnej teza sugerująca ,pominięcie [przez M.K.] przy rozbudowanej analizie przekazu Mistrza Wincentego (s. 270-276) informacji, że można w nim stosunkowo łatwo odszukać ślad istnienia kilku (zapewne co najmniej trzech) tradycji dotyczących Rychezy i Kazimierza Odnowiciela, dodatkowo różniących się w szczegółach oraz oceną poszczególnych osób, co może sugerować istnienie różnych środowisk będących dla Kadłubka źródłem wiadomości” (s. 316). O czym w takim razie traktuje przypis 21 (s. 275-276) 32 ? Nigdzie też, ani bezpośrednio, ani pośrednio, nie wyrażam opinii, że w książce J. Chachaja „znajduje się teza, jakoby Lublin mógł być założony przez Cezara” (s. 316), a wskazany na potwierdzenie tej tezy fragment refleksji (s. 272-274) poświęciłem bez reszty na przywołanie przykładów grodów i miast średniowiecznych, których początki wywodzono w średniowieczu od osoby Juliusza Cezara, a to zupełnie inna gałąź w rozumowaniu. W równej niezgodzie z tekstem rozprawy recenzyjnej pozostaje wreszcie deklaracja Szanownego Polemisty,

31 Zob. K. Myślińs ki, Najstarsyy Lublin - proces tworzenia się średniowiecznego miasta, „Rocznik Lubelski” 9 (1966), głównie s. 150-152 (gdzie także odwołania do poprzednich prac). Dowodem znajomości tej rozprawy podczas przygotowywania przeze mnie rozprawy recenzyjnej jest jej przywoływanie w stosownych miejscach (s. 267 w przyp. 4 , s. $270 \mathrm{w}$ przyp. 9, s. 286 w przyp. 43 , s. 294 w przyp. 61 , s. 297 w przyp. 69).

32 Dla wygody czytelnika przytaczam go in extenso: „Dodajmy, iż wątek wygnania Rychezy z Polski podją Mistrz Wincenty również osobno w swoim utworze - zob. tamże [Magistri Vincentii... Chronica Polonorum, ed. M. Plezia], s. 45 n (lib. II, cap. 14), przedstawiając równolegle dwie wersje wydarzeń. Pierwsza z nich idzie niemalże w całości za Gallem, toteż nie ma potrzeby jej w tym miejscu omawiać. Druga zaś istotnie akcentuje dominującą rolę jakiejś nałożnicy (pellex) Mieszka, która miałaby czyhać na życie małego Kazimierza (co byłoby punktem wspólnym z opowieścią o Julii). Niemniej jednak Mistrz Wincenty nie pozostawia watpliwości, iż ,dicunt enim huius matrem paruuli in ipso partu expirasse [podkreślenie moje - M.K.]”, a „post modicillum uero tempusculi decedit pater [sc. Mieszko - M.K.], proscribitur nouerca [podkreślenie moje - M.K.], regnum destituitur [...]” (cytaty, odpowiednio s. 45 i 46). Różnice pomiędzy opowieściami o Julii i Rychezie (nawet tylko na poziomie Kroniki Mistrza Wincentego) są tak zasadnicze, iż teza o ich paralelności nie wytrzymuje krytyki i musi ostatecznie upaść”. Polifoniczność wyjaśnienia losów Rychezy i Kazimierza wyrażona przez Mistrza Wincentego została tu więc dostrzeżona i oceniona; dodam tylko, że w pełni podtrzymuję pogląd, iż szkielet konstrukcji postaci Julii i Rychezy u Kadłubka więcej dzieli, niż łączy. 
iż: „Nieuczciwe jest [...] sugerowanie, że w pracy nie ma wzmianki na temat dotychczasowego stosunku historiografii do lubelskiego wątku w przekazie Kadłubka [...], bo wystarczy do niej zajrzeć [tu stosowny namiar bibliograficzny - M.K.]" (s. 317). Wystarczy jednak równie dobrze zajrzeć do wskazanego fragmentu mojej ostatniej wypowiedzi (s. 270-271, przyp. 9), aby się przekonać, że taki zarzut (sformułowany en bloc) nigdzie w niej nie pada; znajduje się tam tylko uwaga o braku śladów wykorzystania przez autora jednej z fundamentalnych rozpraw O. Balzera pt. Studyum o Kadłubku. Słuszność tej obserwacji jest możliwa do stwierdzenia obiektywnie; wystarczy przestudiować aparat krytyczny. O wykorzystaniu innych prac w przywołanym miejscu się nie wypowiadam ${ }^{33}$.

„Drugim bardzo ciężkim zarzutem, który pojawia się w recenzji, jest zarzut przedkładania źródeł późniejszych nad wcześniejsze” (s. 319). Stwierdzeniem tym otwiera J. Chachaj ostatni segment swoich zasadniczych rozważań (s. 319-321), powołując się przy tym nie bez słuszności na jedną z konkluzji mojego recenzyjnego oglądu Jego publikacji brzmiącą: „Dziwić musi również niejednokrotnie stosowany przez J. Chachaja zabieg przedkładania świadectwa źródeł późniejszych nad wcześniejszymi, co nie wystawia pracy najlepszego świadectwa pod względem warsztatowym i metodologicznym" (s. 299). Zmierzając do wykazania bezpodstawności tej uwagi, Autor od razu wyjaśnia też czytelnikom: „Rzecz w tym, że w żadnym z tych miejsc nie doszło do "przedkładania» przekazów późniejszych nad wcześniejsze, a jedynie albo do wskazania, że część późnych zapisów może się wiązać $\mathrm{z}$ nieznanymi nam, być może zniekształconymi tradycjami lokalnymi [...] albo z próbą wybrnięcia z sytuacji, w której przekazy źródłowe wydaja się podawać sprzeczne informacje” [podkreślenie moje - M.K.] (s. 319). Sprawdźmy.

Jednemu, modelowemu wręcz przykładowi, dowodzącemu - wbrew deklaracji Szanownego Polemisty - że w ogłoszonych przezeń szkicach historycznych zagnieździły się momenty „przedkładania świadectwa źródeł późniejszych nad wcześniejszymi”, mieliśmy już okazję przyjrzeć się z bliska. Jest nim w całej rozciagłości szkic o rzekomym odnalezieniu w Lublinie (i Kocku?) bezpiecznej przystani przez Gertrudę i Izjasława Jarosławowicza, co - jak mieliśmy już okazję się przekonać - w ogóle nie mogło mieć i nie miało racji bytu za panowania Bolesława Szczodrego w latach 1075-1076 ${ }^{34}$. Docho-

33 Spośród wszystkich wymienionych w tym miejscu rozpraw tylko przy jednej - Studyum o Kadtubku O. Balzera - widnieje adnotacja, iż: „tej fundamentalnej pracy nie przywołuje Autor ani razu w swoich wywodach" (s. 270, przyp. 9). Por. O. Balze r, Studyum o Kadtubku, t. I (1934), s. 283-296, a zwł. 283287.

34 Kamieniem węgielnym całej tej superhipotetycznej konstrukcji jest - jak zwróciłem na to już raz uwagę (s. 279-280, 288-292) - zapiska proweniencji kościelnej z 1595 r., pochodząca z akt wizytacji dóbr archidiakonatu lubelskiego, przeprowadzonej na żądanie kardynała Jerzego Radziwiłła przez archidiakona lubelskiego Jerzego Zamoyskiego (Kraków, Archiwum Kurii Metropolitalnej, sygn. AV Cap. 3, fol. 26r.), jakoby kaplica Trójcy Świętej na Wzgórzu Zamkowym zawdzięczała swój materialny byt jakimś „książętom ruskim”, którzy mieliby uchodzić za jej fundatorów gdzieś około 1057 r. („,circa annum Domini 1057”). Ten zanotowany nad wyraz późną i odosobnioną w tym mniemaniu ręką 
dzą do niego - w analogicznej roli - próby dopisywania do życiorysu Rychezy (w całym szkicu I) nowego rozdziału działalności w postaci otoczenia fundatorską troską pierwocin lubelskiego ośrodka grodowego i to wyłącznie na podstawie zawisłej na włosku autorskiego przekonania paralelności figur Julii i Rychezy w późnej dla wydarzeń z lat 20.-30. XI w. relacji Mistrza Wincentego Kadłubka z przełomu XII i XIII w. Należy powtórzyć z naciskiem: za takim rozwiązaniem nie przemawia żaden „fakt historyczny”, a tym bardziej „fakt źródłowy” (por. obszerne uzasadnienie - s. 268-281). Śledząc losy Rychezy i jej ewentualną aktywność na polu fundacji kościelnych, warto najpierw pytać o to przekaz dużo starszy i podstawowy - Kronike klas ztoru w Branweiler z drugiej połowy XI w. ${ }^{35}$, tudzież - jeśli interesują nas okoliczności jej wygnania/ucieczki z Polski - Kronikę

nowożytnego wizytatora „fakt źródłowy” przerzucił Autor rychło, biorąc poprawkę na niedokładność podanej datacji, ostatecznie na 1075 r. (J. Chach aj, Lublin - miasto Rychesyy?, szczególnie s. 43-44), przez co doszedł dość „płynnie” do osób Gertrudy i Izjasława. Mając pełną świadomość, że żadne starsze przekazy źródłowe nie informują nas ani słowem o okolicznościach fundacji kaplicy Trójcy Św. na Wzgórzu Zamkowym, a nie chcąc zarazem zbyt prędko rozstawać się z wyśledzoną dopiero zapiską wizytacyjną, zapożyczył się też J. Chachaj u najwcześniej XIII-wiecznych (XIV-wiecznych?) zapisek z inwentarza majątkowego biskupstwa płockiego i XV-wiecznego przekazu z Liber beneficiorum J. Długosza. Znamy już wynik próby zaprzęgnięcia tych przekazów do wozu naszego zagadnienia; niedaleko można z nimi ujechać. Doszły do tego więc nawet - w charakterze pomniejszych środków dowodowych - tak niepozorne okruchy jak zupełnie wieloznaczne w swej wymowie nazwy miejscowe wokół Lublina: „Pogost”, „Prawiedniki” czy „Kijany” (połączone pod piórem Autora więzią fonetycznej bliskości z „Kijowianami”) - por. id em, Lublin - miasto Rychesy?, s. 109, 115-117, 127-128. Daleko prościej i bezpieczniej było wszakże obrać za przewodnika znane przecież dobrze Autorowi, nieporównanie lepiej zorientowane w chronologii losów Gertrudy i Izjasława zapisy z Kroniki Lamperta z Hersfeldu i obronić wiarygodność podanej w niej datacji oraz fakt sojuszu Bolesława ze Światosławem aż do zimy 1076 r. z Ponviésica minionych lat w ręku. Przy takim ustawieniu pola deliberacji rychło wyszłoby naprzeciw bardzo nikłe (nawet na skali hipotetyczności) prawdopodobieństwo obrania przez Gertrudę i Izjasława tymczasowego lokum w pogranicznym Lublinie (biorąc - rzecz jasna - poprawkę, że nic nie wskazuje jednoznacznie na to, że gród lubelski wiódł już wówczas rzeczywisty, a nie tylko postulowany żywot). Sumując, godzi się więc zapytać: na których to źródłach opiera się zasadniczy szkielet całych tych autorskich propozycji i hipotez - wcześniejszych i wyposażonych w większą wiarygodność czy też raczej tych późniejszych metrykalnie?

35 Mimo dochowania się do naszych dni Kroniki klasztornej z Brawweiler jedynie w późnych, nowożytnych kopiach, opatrzonych przez to - jak zawsze w tego typu przypadkach - wieloma błędnymi lekcjami, nie ma wśród zgłębiających ją kompetentnych badaczy cienia wątpliwości, że chronologię jej powstania (nie licząc prób kontynuacji) należy wiązać najpewniej z początkiem ostatniej ćwierci XI w. (ok. 1080 r.), a zupełnie bezpiecznie - z druga połową XI w. Tradycję rękopiśmienną omówili najpierw wydawcy - zob. Fundatio monasterii Brunwilarensis, ed. H. Pabst, „Archiv der Gesellschaft für ältere deutsche Geschichtskunde" 12 (1874), s. 82-90 oraz Brunwilarensis monasterii fundatorum actus, rec. G. Waitz, [w:] Monumenta Germaniae Historica. Scriptores, Bd. XIV, Hannoverae 1883, s. 122-123 oraz zupełnie ostatnio wytrawny jej znawca na polskim gruncie M. Tomaszek, Auf der Suche nach dem neuen Schutzheiligen - zur Frage der Datierung und Motivation zur Geschichtsschreibung über die Anfänge der Brauweiler Benediktinerabtei, „Quaestiones Medii Aevi Novae” 14 (2009), s. 186-189. Do ustalenia chronologii całego zabytku zob. E. Müller-Mertens, Regnum Teutonicum. Aufkommen und Verbreitung der deutschen Reichs- und Königsauffassung im frühen Mittelalter, Wien-Köln-Graz 1970, s. 262-272; P. Schreiner, Benediktiner in Brawweiler. Geschichte der Benediktinerabtei St. Nikolaus 1024-1802, Pulheim 1988, s. 57-59 oraz ostatnio H.E. Stiene, Zwischen Glorie und Elend. Geschichtsschreibung in der Abtei Brauweiler im 11. und 
Galla-Anonima. Jak jeden mąż nie wiedzą one zgoła nic na temat rozważanej aktywności fundatorskiej Rychezy na wschodnich rubieżach pierwszej monarchii piastowskiej, co musi być poczytane za znamienne. Taką samą niewiedzę daje się zdiagnozować u Mistrza Wincentego, który - gdy doszły do jego uszu strzępy dawnych, już to możnowładczych, już to dworskich, już to kościelnych tradycji środowiskowych o Rychezie, porozmieszczał te okruchy zgromadzonych wiadomości w adekwatnym miejscu, wkomponowując je płynnie w opis jej wygnania wraz z synem Kazimierzem z Polski w dobie tzw. kryzysu monarchii piastowskiej na przełomie lat 20./30. XI w. Sfingowana literacko postać Julii (jako założycielki Julina-Lublina) została przezeń urobiona z zupełnie innego tworzywa estetyczno-erudycyjnego, do czego nieuchronnie prowadzi porównanie schematów narracji o Julii i Rychezie (por. takie zestawienie - s. 275-276). Wracamy więc nolens-volens znów do pytania wyjściowego - jakież to źródła legły u podstaw całej tej konstrukcji: wcześniejsze, darzone zgodnie i słusznie dużym zaufaniem i niewiedzące nic o domniemanych powiązaniach Rychezy z Lublinem (Kronika klasztoru w Brawweiler, Kronika Galla Anonima) czy osobliwie autorsko zinterpretowane, aby pogodzić z nim zapiski nowożytne, źródło dużo późniejsze (Kronika Mistrza Wincentego)?

Równie, o ile nie bardziej eksponowane miejsce w kartotece wypadków „przedłożenia świadectwa źródeł późniejszych nad wcześniejsze” przez J. Chachaja zajmuje - mimo innego w tej sprawie zdania mojego Oponenta (s. 319-321) - podana przezeń wykładnia i garść dostarczonych propozycji analityczno-interpretacyjnych w sprawie epizodu najazdu książąt halickich Daniela i Wasylka na gród lubelski w 1244 r. Ponieważ obrane przez nas obu drogi egzegezy tego wydarzenia rozchodzą się w sposób zasadniczy, wymaga ono wyjątkowo uważnej i starannej analizy, biegnącej od odczytania i wsłuchania się w wymowę „,faktów źródłowych” do ukonstytuowania na ich bezpiecznym podłożu „faktów historycznych”.

Zapis o najeździe ruskim na Lublin w 1244 r. był z całą pewnością wciagnięty współczesną ręką do tzw. Rocznika kapituly krakowskiej (dawnego), inaczej: Annales Regni Polonorum deperditi [dalej: ARPD], z którego czerpały - po zakończeniu doń wpisów ok. 1266 r. pośrednio lub bezpośrednio późniejsze zabytki małopolskiej annalistyki ${ }^{36}$. Wśród wszystkich tych roczników uwagę zwracają w pierwszej linii te, do których przeniknęła ta in-

12. Jahrhundert, „Pulheimer Beiträge” 29 (2005), s. 22 i n., a zwł. 25-39. Por. jeszcze E. Wisplinghoff, Die Benediktinerabtei Brauneiler, [w:] Germania Sacra. Neue Folge, Bd. 29, Berlin-New York 1992, s. 37-39, 136-137.

36 Zob. tutaj w kolejności starszeństwa najpierw zapiskę Rocそnika kapitulnego krakowskiego, rec. Z. Kozłowska-Budkowa, [w:] Annales Cracovienses priores cum Kalendario, MPH ser. nova, t. V, Warszawa 1978, s. 80 (sub anno 1244): „,[P]ruteni per diversos insultus Lublin devastant et ecclesias succendunt. Kylcia per milites ducis Cunradi devastatur", dalej zaś zredagowane później: a) Rocznik krótki, rec. Z. Kozłowska-Budkowa, ibidem, s. 241 (sub anno 1244): ,[P]ruteni per diversos [insultus] Lublin devastant et succendunt", b) Ročnik krakonski, wyd. A. Bielowski, [w:] MPH, t. II, Lwów 1872, s. 838 (sub anno 1246): „Ruteni per frequentes insultus Lublin, Seczechov et Lacow vastant” oraz c) 
formacja, a zatem najpierw czerpiący z ARPD bezpośrednio Rocznik kapitulny krakowski, dalej zaś mające z ARPD pośrednią łączność filiacyjną Rocznik krótki, Rocænik krakowski oraz Rocznik Traski, które zgodnie podaja jedynie, że Rusini przypuścili atak na gród lubelski i zaprószywszy ogień w tamtejszych świątyniach, sprofanowali je (Rocznik krakowski oraz Traski rozciagaja jeszcze tę obserwację na Sieciechów i Łuków) ${ }^{37}$. Amplifikowaną redakcję tej zapiski przynosi dopiero tzw. Rocznik świętokrayyski (nowy), który pod rokiem 1244 podaje: „Rutheni per diversos insultus Lublin et totum territorium devastant et succedunt et castrum per se edificare ceperunt et turrim muratam fecerunt" ${ }^{38}$. Elementem zupełnie nowym, nadbudowanym na starszej annalistycznej konstrukcji, jest w tej redakcji wiadomość o budowie w grodzie lubelskim murowanej wieży, co miałoby nastapić po zdobyciu go przez najeźdźców. I wreszcie Jan Długosz, rozwodząc się dość obszernie nad wypadkami 1244 r., tak je sobie wyobrażał: „Ruthenorum et Kyoviensis princeps Daniel, terre Lublinensis solitudine et desertacione comperta, exercitualiter in Lublin adveniens, tam arcem quam civitatem capit et universam terram Lublinensem sibi appropriat et usurpat. Et quo sibi et suis posteris diuturnior sit illius occupatio, turrim rotundam ex coctis lateribus in castri medio, habentem in summitate circuitum et propugnacula, mira celeritate edificat castrumque et civitatem fossis et vallis profundis fortificat et omnes Lublinensis terre militares et inhabitatores sibi parere cogit" ${ }^{\prime 39}$. Rzuca się w oczy, że przekaz Długoszowy stanowi znów amplifikowaną wersję zapiski z Ročnika Świetokrzysskiego (nowego), a każdy, kto uważa przeciwnie, powinien znaleźć inne źródło, z którego kronikarz zaczerpnął faktograficzną osnowę swojej narracji.

Zupełnie inaczej widzi natomiast tę kwestię źródło ruskie, Kronika balicko-wołyńska, zachowana wprawdzie - jak słusznie podnosi J. Chachaj (s. 320) - najwcześniej w XV-wiecznym Latopisie hipackim, ale stanowiąca bez cienia wątpliwości dzieło XIII-wieczne ${ }^{40}$.

Rocznik Traski, wyd. A. Bielow ski, ibidem, s. 838 (sub anno 1244): „Prutheni per frequentes insultus Lucow et Lublin et Sccechow devastant".

37 Uderzająco zgodna stylizacja tych zapisek (z kontekstu wydarzeń lekcja „Prutheni” jawi się jako klasyczny hapax legomenon, co definitywnie ustaliła - przy braku sprzeciwu ze strony innych uczestników debaty Z. Kozłowska-Budkowa - MPH ser. nova, t. V, s. 80 z przyp. 297, 241 z przyp. 36, a zaaprobował ostatnio również J. Chachaj, Poczatki lubelskiego ośrodka, s. 176, przyp. 32) oraz materiał informacyjny, który niosa, pozwala na wyciagnięcie wniosku, że w pierwotnej zapisce w Roczniku kapitulnym krakowskim (dawnym) nie było dodatkowych informacji na temat najazdu(-ów) Daniela halickiego na Lublin poza prostym faktem oblężenia grodu, połączonego ze spaleniem świątyń, i dewastacji okolicy przez agresora. Obserwację tę należy stale zachowywać w pamięci.

38 Annales S. Crucis, ed. A. Rutkowska-Płachcińska, MPH ser. nova, t. XII, Cracoviae 1996, s. 39-40.

39 Ioannis Dlugossii Annales seu Cronicae incliti Regni Poloniae, lib. VII-VIII, textum rec. D. Turkowska, adiutrice M. Kowalczyk, Varsaviae 1975, s. 47.

40 Aby wyrobić sobie właściwy pogląd na problem datacji tego dzieła, należy najpierw zapoznać się z kompetentnym głosem A. Poppe, Latopis ipatjenski (hipacki), [w:] SSS, t. III, red. W. Kowalenko, G. Labuda, T. Lehr-Spławiński, Wrocław-Warszawa-Kraków 1967, s. 20-21, który wskazuje, że 
Według tej bliskiej opisywanym wydarzeniom relacji wojska Daniela (do spółki z jego młodszym bratem Wasylkiem), kontynuując serię najazdów na ziemię lubelską i posłyszawszy o kontruderzeniu sił polskich pod Andrzejowem, istotnie podeszły z miotajacymi machinami oblężniczymi pod gród lubelski, pustosząc zarazem tamtejszą okolicę, ale od oblężenia tego po dłuższym czasie odstapiły, zadowalając się obietnicą złożoną przez załogę, iż odstapi ona od wspierania racji i dążeń „swojego pana”, czyli Bolesława Wstydliwego, do panowania w Krakowie. O fakcie zdobycia grodu, a co więcej - budowy jakiejkolwiek murowanej wieży - Kronika halicko-wolyńska nie wie zgoła nic, które to milczenie musi zastanawiać, zwłaszcza że zachowuje je też najstarsza rekonstruowana powyżej zapiska z ARPD ${ }^{41}$. Wiadomość o budowie wieży w Lublinie stwierdzalna jest

w skład Latopisu hipackiego wchodza: a) tekst Powieśsi minionych lat w trzeciej redakcji roku 1118, b) zwód kijowski wielkiego księcia Ruryka Rościsławowicza redakcji ihumena wydubickiego Mojżesza oraz c) Latopis halicko-wotyński, urywający się na 1292 r. i rozpadający się na dwa de facto oddzielne utwory: 1) Latopis Daniela (jednolity w formie, powstały około 1258 r.) oraz 2) Latopis Wasylka (brata Daniela) i jego syna Włodzimierza, zespolone najprawdopodobniej w jedną całość ok. 1289-1290 r. za rządów Mścisława Daniłowicza. Ogólnie XIII-wieczną datację potwierdza ostatnio D. Dąbrowski, Uczestnicy wydarzeń gasawskich 1227 roku w świetle przekazón Kroniki halicko-wotyńskiej, [w:] Gasawa w pamieci bistorycznej w zwiazku z 620. rocznica lokacii miasta, red. D. Karczewski, Inowrocław 2009, s. 93-94; i dem, Kronika balicko-wotyńska jako źródto do studiów nad kultura ma te rialn a średniowiecznej Rusi. Ogólna charakterystyka i postulaty badawcze, „Kwartalnik Historii Kultury Materialnej” 61 (2013), $\mathrm{nr} 1$, s. 63 (w przyp. 1-2 stosowny przegląd dalszej literatury). Ukoronowaniem wieloletnich zabiegów analitycznych i interpretacyjnych wokół tego zabytku jest ostatnia wzorcowa jego edycja krytyczna: Chronica Galliciano-Voliniana (Chronica Romanoviciana), ed. D. Dąbrowski, H. Ju supović, adiuv. I. Juriewa, A. Majorov, T. Wiłkuł, MPH ser. nova, t. XVI, Cracoviae-Varsoviae 2017, tutaj też znakomity wstęp (zwł. opis kodykologiczny zachowanych rękopisów [s. XIV-XXX] z wyborem najbliższego archetypowi tzw. rękopisu chlebnikowskiego jako podstawy wydania [s. XIV-XIX] oraz stemma codicum [s. LXI] i instruktywny przegląd opinii na temat datacji i autorstwa Kroniki [s. LXIILXXVI], z wyważona, ostrożną opinią wydawców [s. LXXIV-LXXVI], dla tzw. Kroniki dworskiej Daniela przyjmujaca dwie redakcje - starszą: ok. 1246/1247 r. i młodsza: ok. 1258-1264 r.). Na czytelników wyglądających polskiego tłumaczenia czeka Kronika balicko-wotyńska. Kronika Romanowiczón, tłumaczenie, wstęp i komentarze D. Dąbrowski, A. Ju supović, Kraków 2017. Obserwacje Wydawców prowadzą więc w prostej linii do potwierdzenia powszechnie znanej i na ogół uznawanej reguły, iż w sytuacji, gdy oryginał danego zabytku uchodzi za zaginiony, to normatywnie dalej on (a nie najstarsze kopie) oznacza chronologię powstania całości, co słusznie przypomniał niedawno J. Bieniak w dyskusji z M. Cetwińskim nad referatem K. Kollingera, [w:] Onus Atblanteum. Studia nad Kronika biskupa Wincentego, red. A. Dąbrówk a, W. Wójtowicz, Warszawa 2009, s. 201-207.

Zob. Полное собрапие русских летописей, t. 2: Ипатьевская летопись, wуd. 2, Санкт Петербург 1908, kol. 796-797 (pod rokiem 1245). Cytuję najważniejszy fragment (z przyjęta dla tego wyd. interpunkcja i odczytem paleograficznym tekstu): „оуслышавъ же Данило кнАзь со братомъ Василкомъ. совокоупиша силоу свою. И повельста. престроити праща. и иныие сосоудыи на взАтье града. и придоста на градъ Люблинъ. Єдиного дне быссста подъ градомъ ис Холма. со всими вои и пращами. мечющимъ же пращамъ . и стръламъ гако дождоу идоущоу на град ихъ. и оуведевъше ЛАхове. гако крьпчЂе брань Роускага. належить. начаша просити млсть полоучити Даниль же и Василко створиста. завьтъ. положивъ имь реко не помогаите кнзю своемоу шни же шбъщасл то створити. Данилъ же со братомъ возвратистасА. воевавша страноу тоу". W prymarnej wersji obecnego tekstu korzystałem z klasycznego i powszechnie cytowanego do niedawna wydania A. Szachmatowa; teraz odwołuję się również do edycji: Chronica 
dopiero w Roçniku Świętokrąyskim nowym, który, sam zredagowany w ostatniej dekadzie XIV w. (ok. 1399 r.), nie czerpał bezpośrednio z zapisów Rocznika kapitulnego krakowskiego (zaginionego), ale wywodzi się ze zredagowanej po 1325 r. tzw. redakcji A2 praźródła roczników małopolskich Annales Polonorum deperditi i w wielu wypadkach zawiera amplifikacje w porównaniu do wyjściowego materiału rocznikarskiego rodem z XIII w. ${ }^{42}$

W obecnej konfiguracji źródłoznawczej wiadomość o budowie z nakazu księcia Daniela halickiego wieży w Lublinie podczas jego oblężenia w połowie lat 40. XIII w. jest więc tylko „faktem źródłowym”, który zanotowany w przekazie zredagowanym ewidentnie później niż Kronika halicko-wołyńska i wykazującym nieraz wyraźne tendencje amplifikacyjne, nie daje się metodycznie podnieść do rangi „faktu historycznego”.

Postawione przez J. Chachaja w replice pytanie (s. 320), w jaki sposób powstał błędny zapis „w rocznikach polskich”, uzyskało zatem wyczerpująca odpowiedź, która przecina zarazem inną bolączkę, czy pozostałością postulowanej wieży Daniela nie mogłaby być - jak chce to rozważyć mój Oponent (s. 319-320) - albo tzw. sala na jednym słupie (wchodząca aktualnie w skład kompleksu klasztornych zabudowań dominikańskich w Lublinie), albo tzw. wieża dominikańska (przetrwała w formie reliktów w kamienicy przy ul. Dominikańskiej 7). Wobec zanegowania na gruncie źródłowym i źródłoznawczym wiarygodności informacji o budowie z rozkazu Danielowego jakiejkolwiek wieży w Lublinie (tudzież okolicy), dalsze dywagacje nad tą kwestią tracą nieodwracalnie rację bytu. Jeżeli natomiast gotów jest J. Chachaj mimo wszystkich watpliwości wziąć przekaz źródeł polskich za dobrą monetę, winniśmy spodziewać się odeń wyjaśnienia, dlaczego o zdobyciu grodu lubelskiego i budowie w nim okazałej murowanej wieży nie wie zgoła nic źródło powstałe w bezpośrednim otoczeniu Daniela halickiego w bardzo krótkim czasie po owym najeździe? Wbrew surowym zastrzeżeniom wyrażonym przez Oponenta

Galliciano-Voliniana, ed. D. Dąbrowski, A. Jusupović, s. 261-262; por. też Kronika balicko-wotyńska (Kronika Romanowiçón), tłum. i oprac. D. Dąbrowski, A. Jusupović, s. 169-170.

42 Kompetentnie ustalił to W. Drelicharz, Annalistyka małopolska XIII-XV wieku. Kierunki rozwoju wielkich rocznikón kompilowanych, RAU whf, t. 99, Kraków 2003, zwł. s. 263-280 oraz s. 469 (Stemma codicum). Nawet na pierwszą dekadę XV w. datuje natomiast Rocznik Świętokrzyski (nowy) P. Węcowski, Strata korony królewskiej po śmierci św. Stanisława w opinii pisarzy późnego średniowiecza, [w:] Christianitas Romana. Studia ofiarowane Profesorowi Romanowi Michatowskiemu, red. K. Skwierczyński, Warszawa 2009, s. 281 (przyp. 34). Wiadomość o budowie wieży w Lublinie przez Rusinów mogła zatem zostać po upływie lat mylnie powiązana z 1244 r., zwłaszcza że gród ten znalazł się - jak wiadomo - przejściowo pod ich władzą na przełomie XIII/XIV w. Dokładniej omawia ten problem K. Myśliński, Problemy terytorialne w stosunkach miedsy Polska i ksiestwem halicko-wtodzimierskim w XIII wieku, [w:] Nibil superfluum esse. Studia z dziejón średnionviecza ofiarowane Profesor Jadwidze Krzyżaniakowej, red. J. Strzelczyk, J. Dobosz, Poznań 2000, s. 234-236. Inne hipotezy w sprawie osoby fundatora donżonu na Wzgórzu Zamkowym w Lublinie kompetentnie zreferował ostatnio M. Florek, Zamek w Lublinie, s. 27-29, sam oświadczając się ostatecznie za niewymienianym dotąd w tym kontekście Wacławem II czeskim (s. 29-30). Do momentu przeprowadzenia fachowych badań archeologicznych, co podnosi też sam autor (s. 27-28), kwestia ta musi pozostać otwarta, choć osiagnięte dotąd wyniki raczej bezpowrotnie eliminują z listy potencjalnych zleceniodawców budowy Daniela halickiego. 
zastosowany przeze mnie tak uprzednio, jak obecnie schemat postępowania nie ma więc bynajmniej nic wspólnego z bezrefleksyjnym uprawianiem historii (por. s. 320). Nie jest to też - że znów odwołam się do Jego własnych słów - „droga donikąd” (s. 320); jest to droga krytyki źródeł.

Przeszedłszy do końca proces krytycznej weryfikacji racji merytorycznych zgłoszonych w ostatnim głosie polemicznym J. Chachaja, godzi się dostrzec osobno, iż z wypowiedzi tej daje się też wyłowić, co gorsza, kilka ewidentnych argumentów ad personam, które - jak powszechnie wiadomo - nie przydają blasku jakiejkolwiek wymianie pogladów, a tym bardziej dyspucie naukowej ${ }^{43}$. Z oczywistych względów nie zamierzam się do nich odnosić, poza jednym wyjątkiem, który wymaga zdecydowanego dementi. Chodzi o sugestię, iż w ogłoszonej rozprawie recenzyjnej piszący te słowa miał jakoby postapić nierzetelnie zawodowo, a także nieuczciwie wobec czytelnika, zapożyczając rzekomo z pracy swojego Oponenta tworzywo do przypisów we własnym artykule i nie sygnalizując takich kroków.

Zarzut ten - ze względu na obiektywnie w nim tkwiący znaczny ciężar gatunkowy - wymaga przytoczenia w całej rozciagłości: „Czytelnik, który zapozna się z recenzja, nie sięgając do będącej obiektem recenzji pracy, może odnieść wrażenie, że obfita literatura i przypisy służą wykazaniu bezpodstawności zawartych w niej »piętrowych hipotez«. Tymczasem wystarczy zestawić kilka miejsc w pracy i recenzji, by przekonać się, że także pod tym względem M. Kosonowski postępuje co najmniej nierzetelnie. Znaczna

43 Aby nie pozostać gołosłownym, wystarczy przypomnieć tu następujące, a dobrze ilustrujące tę prawidłowość stwierdzenia (wszystkie wyróżnienia moje - M.K.): „Napisanie bardzo długiej recenzji było pretekstem do drobnych złośliwości, na które Recenzent nie mógłby sobie pozwolić, gdyby musiał pamiętać o rozmiarach swojego tekstu” (s. 310, przyp. 2), „Dodatkowo w obecnej postaci pojawia się pytanie o zgodność tytułu artykułu z jego treścią, co wydaje się rzeczą wielce zaskakująca u człowieka, który szczyci się tym, że studiuje na jednej z najbardziej szacownych uczelni w Polsce” (s. 310, przyp. 3), „Po przeczytaniu takiej recenzji, gdybym nie znał treści swojej książki, zapewne nie poświęciłbym czasu na jej lekturę. Jest to jednak nieuczciwe nie tylko wobec mnie, ale przede wszystkim wobec czytelnika, który przeczyta recenzję, nie znając treści pracy” (s. 311), „Ma [recenzent - M.K.] także dużą śmiałość (chwila mi posunięta do zuchwałości) formułowania sądów” (s. 312), „Na charakter pracy, której recenzję postanowił Autor napisać, powinien zresztą naprowadzić człowieka o takiej erudycji już sam jej tytuł” (s. 313-314), „W recenzji łatwo dostrzec także kilka innych manier. Jedną z nich jest zawo dowa nierzetelność lub wręcz nieuczciwość” (s. 317), „Wydaje się on [tj. recenzent] nie rozumieć ani charakteru, ani treści recenzowanej pracy, stawiając zarzuty niewykorzystania literatury, zdaje się nie wiedzieć, na czym polega korzystanie z dotychczasowych ustaleń, zarzucając przedkładanie źródeł późniejszych nad wcześniejsze, jest całkowicie bezradny w sytuacji sprzeczności wymowy przekazów źródłowych i ma poważne kłopoty z rzeczywistym ich datowaniem” (s. 321), „Wydaje się, że powinien wziąć sobie do serca [recenzent] także inne słowo, które brzmi: »dojrzeć« (i to w obydwu jego znaczeniach). Trzeba bowiem zwyczajnie dojrzeć do tego, by umieć dojrzeć to, co istotne w uprawianej przez siebie dziedzinie. Recenzent już potrafi wykazać się znajomością literatury i źródeł, a przynajmniej stworzyć wrażenie takiej znajomości (inna rzecz, czy potrafi w rozumny sposób wykorzystać ich treść) oraz podejmować dość bezkompromisowe polemiki” (s. 323). 
część rozbudowanych przypisów znajdujących się w recenzji jest bowiem w większości zbieżna z zawartością przypisów zawartych w pracy, choć w kilku miejscach zostały one uzupełnione oraz z reguły poszerzone o obfite cytaty. Przykładów stosowania tej metody jest w pracy wiele. Przypis 17 na s. 274 jest zbieżny, nawet co do cytowanych stron, z przypisem 34 na s. 26 recenzowanej pracy [ściślej różnica jest taka, że M. Kosonowski przywołuje tylko starsze wydanie pracy, a w recenzowanej książce podane są także strony, gdzie interesujący nas fragment znajduje się także w nowym wydaniu], przypisy 29 i 30 (s. 279) zdecydowanie nawiązują treścią do przypisów 50 i $51 \mathrm{w}$ pracy, a Recenzent z otwartą szczerością przyznaje pod koniec przypisu 29, że »zupełnie nie wiadomo czemu miało służyć tak obfite zestawienie zapisów tzw. schematyzmów diecezji lubelskiej«, które to zapisy znajdują się w przypisie 51], itd.” (s. 320-321). Wywód ten znajduje też dopełnienie w jednej z konkluzji: „Dodatkową (ale konieczna, bo jej lekceważenie może powodować równie przykre skutki) umiejętnością wobec wskazanej wyżej jest także sztuka takiego sporządzania aparatu naukowego, by nie zachodziło podejrzenie, że Recenzent, nie wspominając o tym, korzysta z prac innych” (s. 323) [wszystkie podkreślenia moje - M.K.]. Innymi słowy, zachodzi konieczność odparcia jednego z najcięższych, jeśli nie najcięższego zarzutu, jaki można postawić oponentowi w sferze naukowej - zarzutu plagiatu.

Wprawdzie przykładów na stosowanie tego haniebnego zabiegu miało być w moim artykule wiele, ale J. Chachaj naprowadza tylko na trzy, z których wszystkie są nie tylko skrajnie wątłe, ale też zupełnie błędne. Aby się o tym przekonać, wystarczy porównać ze sobą brzmienie odpowiednich przypisów w recenzowanej pracy oraz artykule recenzyjnym. Zestawimy ze sobą synoptycznie te fragmenty, wyróżniając kluczowe słowa tłustym drukiem.

M. Kosonowski, Czy królowa Rycheza...

s. 274 (przyp. 17) - przytaczam in extenso: „Zob. J. Banaszkiewicz, Polskie dzieje bajeczne, s. 268 i n." [wcześniej - s. 270, przyp. 9 - odwołanie do wyd. 1 (1998) z zakresem s. 266-276 (jako odnoszących się do legendy o założeniu Lublina przez córkę Cezara)].
J. Chachaj, Lublin - miasto Rychezy...

s. 26 (przyp. 34) - przytaczam in extenso: „J. Banaszkiewicz, Polskie dzieje bajeczne Mistrza Wincentego Kadtubka, Wrocław 1998, s. 267-273 (wyd. 2: Wrocław 2002, s. 259-265)". 
s. 279 (przyp. 29) - przytaczam in extenso: „Zestawienie literatury - zob. np. A. Różycka Bryzek, Bizantyńsko - ruskie malowidła w kaplicy Zamku Lubelskiego, Warszawa 1983, s. 11 i n; por. też M. Brykowska, Królewska kaplica Świętej Trójcy na Zamku w Lublinie w świetle badań architektonicznych i porównawczych, [w:] Kaplica Trójcy Świętej na Zamku Lubelskim. Historia, teologia, sztuka, konserwacja. Materiały sesji zorganizowanej w Muzeum Lubelskim 24-26 kwietnia 1997 roku, red. B. Paprocka, J. Sil, Lublin 1999, s. 2527. Kolejne prace na temat prawdopodobnej daty powstania zabytku wymienia Autor (s. $32-35$ wraz z p. $50-51)$.

Przy okazji warto jednak zauważyć, że zupełnie nie wiadomo, czemu służyć ma tak obfite zestawienie zapisów z tzw. schematyzmów diecezji lubelskiej (blisko 45 różnych wersji z lat 1876 - 1932!), skoro bezpośrednio potem zostało zaznaczone, że »wiadomości te nie mają żadnej podstawy źródłowej « (s. 35 w p. 51 )". s. 279 (przyp. 30) - przytaczam in extenso: „Kraków, Archiwum Kurii Metropolitalnej, Acta Visitationis, sygn. AV Cap. 3 (tutaj: Acta Visitationis ecclesiarum in archidiaconatu Lublinensi ubilibet consistentes per reuerendum dominum Georgium Zamoyski de Zamoście archidiaconum Lublinensem et canonicum Cracoviensem gesta et obseruata sequuntur sub anno Domini MD.XC quinto) [dalej: Akta wizytacji 1595], f. 26 r - „Reverendus $\mathrm{d}$ (ominus) archidiaconus, continuans visitationem suam, visitauit cappellam [sic!] regiam tituli Sanctae Trinitatis in arce Lublinensem sitta [sic!]. Quęquis [sic!] cappella [sic!] praefata antiquitus per duces Russiae constructa est, prout apparet ede [sic!] pictura et scriptura parietum, et hoc circa annum Domini 1057. Restaurata autem et consecrata anno Domini 1401, prout etiam apparet ede [sic!] scriptura in pariete reperta". s. 32 (przyp. 50) - z długiego przypisu przytaczam kluczowy fragment odsyłający do prac A. Różyckiej-Bryzek i M. Brykowskiej, na które obaj się powołujemy: „[...] Stan badań nad zagadnieniem czasu powstania kaplicy wyczerpująco przedstawiła Anna Różycka-Bryzek: A. RóżyckaBryzek, Bizantyńsko-ruskie malowidła w kaplicy zamku lubelskiego, Warszawa 1983, s. 11-12. [...] Za panowania Władysława Jagiełly miały natomiast nastąpić niewielkie zmiany architektoniczne w kaplicy.

M. Brykowska, Królewska kaplica Świętej Trójcy na Zamku w Lublinie, [w:] Sztuka okoto 1400. Materiaty Sesji Stowarzyszenia Historyków Sztuki, Poznań, listopad 1995, t. 1, Warszawa 1996, s. 127145 (zwłaszcza 129-130, 132-133, 140) [do tej pracy nie nawiązuję - M.K.]; taż, Królewska kaplica Świętej Trójcy na Zamku lubelskim w świetle badań architektonicznych i porównawczych, [w:] Kaplica Trójcy Świętej na Zamku Lubelskim. Historia, teologia, sztuka, konserwacja. Materiały sesji zorganizowanej w Muzeum Lubelskim 24-26 kwietnia 1997 roku, Lublin 1999, s. 25, 30, 32, 36 ".

s. 33-35 (przyp. 51) - z długiego przypisu przytaczam odpowiednio opis bibliograficzny rękopisu oraz cytat źródłowy: „Archiwum Krakowskiej Kapituły Katedralnej (dalej AKKK), depozyt w Archiwum Kurii Metropolitalnej w Krakowie (dalej AKMK), sygn. AV Cap. 3: Acta visitationis ecclesiarum in Archidiaconatu Lublinensi ubilibet consistentes. Per Reuerendum Dominum Georgium Zamoyski de Zamoście archidiaconum Lublinensem et canonicum Cracoviensem gesta et obseruata sequuntur sub anno Domini MD.XC quinto (dalej: Wizytacja 1595), k. 26. Jest to informacja niepowtarzana przez inne źródła aż do XIX w. [...]”.

cytat ze źródła archiwalnego in extenso - s. 35 (przyp. 52) - „Wizytacja 1595, k. 26: »Capella prefata antiquitus per Duces Russiae constructa est, prout apparet eoe pictura et scriptura parietum, et hoc circa Annum Domini 1057. Restaurata autem et consecrata Anno Domini 1401 prout etiam apparet eoe scriptura in pariete reperta $\ll$. 
Pomijając kwestię zasadnicza, że w przyp. 29 (s. 279) ogłoszonego artykułu przywołuję pracę Szanownego Polemisty (co przy założeniu nieuczciwych zamiarów jest niewytłumaczalne), trudno nie dojrzeć równie rzucającej się w oczy obserwacji, że wszystkie podane przez J. Chachaja przykłady obracaja się z cała moca przeciw Jego tezie. Zaobserwowane podobieństwa $\mathrm{w}$ opisach bibliograficznych $\mathrm{z}$ literatury zagadnienia tłumaczą się prostym i podstawowym faktem, że korzystaliśmy obaj niezależnie od siebie z różnych, adekwatnych w konkretnym miejscu, klasycznych publikacji, referujących dotychczasowy stan wiedzy w danym zakresie i do nich odsyłamy czytelników, co jest zjawiskiem naturalnym w dyskusji naukowej. Najkrótsza droga do tego wniosku prowadzi przez porównanie brzmienia tych zapisów wraz z zakresami cytowanych stron, gdzie - wbrew temu, czego można się doczytać w polemice - występują jednak rozbieżności. W przypadku zaś źródła archiwalnego, wobec braku jego edycji krytycznej, niepodobna było nie zacytować i nie skomentować tak ważkiego dla wywodu świadectwa ${ }^{44}$. Konkluzja z powyższego zestawienia może więc być tylko jedna - obie strony korzystały na potrzeby swoich opracowań niezależnie od siebie z podstawy źródłowej i wypowiedzi historiografii, co odprawia ostatecznie zasadność zarzutu o plagiat. Warto wreszcie - domykając już ten wątek - uprzejmie zapytać, czy wprowadzając do dyskusji słabo znane źródło, na którego zapisach oparto ważką część własnych dociekań, nie było najlepszym rozwiązaniem zamieszczenie jego podobizny fotograficznej osobno, a nie tylko cząstkowej $\mathrm{i}$ to $\mathrm{w}$ dodatku w niskiej rozdzielczości na przedniej okładce?

Piszący te słowa ma także świadomość, że jego poprzednia wypowiedź została, co gorsza zupełnie wbrew jego intencjom, potraktowana jako atak personalny na osobę Szanownego Polemisty, Jego Mistrzów oraz lubelskie środowisko naukowe (,Wyrwane ze wstępu recenzowanej pracy zdanie o problemie lokalnego lubelskiego środowiska dotyczącym początków miasta ma inną wymowę, gdy wypowiadane jest przez kogoś, kto należy do tego środowiska [...], zaś zupełnie inną, gdy wypowiada je człowiek, który skrzętnie ukrywa, że coś go z tym miastem łączy. Jest to wtedy bowiem niezbyt taktowny atak na całe środowisko, dodatkowo przeprowadzony w sposób mogący je wewnętrznie

44 Dla uniknięcia jakichkolwiek dwuznaczności powiadamiam też, że przekaz ten znany mi był i jest z autopsji, której dokonałem w Archiwum Kurii Metropolitalnej w Krakowie w trakcie prac nad rozprawą recenzyjną. Prawdziwość tej deklaracji sprawdzi każdy, kto skorzysta na miejscu z tego manuskryptu i zerknie do dołączonej do niego metryczki, gdzie widnieje podpis i data. Dodatkowym dowodem w tej materii jest fakt, że cytat przytoczony przeze mnie jest dłuższy i dokładniejszy. Jak byłoby to możliwe, gdyby piszący te słowa miał do dyspozycji tylko cytat podany przez swojego Oponenta w Jego pracy, a nie dysponował zarazem - jak wszyscy - żadnym wydaniem krytycznym całości zabytku? W manuskrypcie wizytacji nie występuje też błędna i niezrozumiała na gruncie zasobu leksykalnego języka łacińskiego lekcja „eoe” (jak podaje J. Chachaj), ale zmonoftongizowana w nagłosie forma „ede” (= aede) - „, świątyni”, przy czym „d” zapisane jest w charakterystyczny nie tylko dla XVII w. sposób z horyzontalnie pochylonym i zgiętym lewoskrętnie trzonkiem laski, co mogło spowodować złudzenie optyczne, że podwójne „e” rozdziela „o”, a nie „d”. 
antagonizować" - s. 323-324). Sprawę trzeba zatem dla ogólnej transparentności postawić jasno - wszystkie, przeważnie dość surowe, słowa krytyki, które padły z mojej strony w poprzednim artykule, były i są skierowane tylko i wyłącznie pod adresem pracy J. Chachaja, osiagniętych w niej rezultatów poznawczych oraz metodologicznej drogi dojścia do tych rozwiązań. Nie był i nie jest ich adresatem z oczywistych względów osobiście jakikolwiek reprezentant lubelskiego środowiska naukowego (w tym sam J. Chachaj). Autor tych słów nie ukrywał też nigdy i nie zamierza ukrywać, że z Lublinem (jako miastem rodzinnym i miejscem, gdzie zdobył całą swoją przeduniwersytecką edukację) łączy go wyjątkowa i niczym niezastępowalna więź. Można więc tylko żałować, że głos ten został opacznie przyjęty jako przyczynek do wzbudzania wewnętrznych niesnasek, a nie (jaki był i jest jego jedyny cel) jako wypowiedź służąca źródłowej i rzeczowej weryfikacji analiz, hipotez i propozycji badawczych zgłoszonych ostatnio przez mojego Oponenta.

Zbierając przeto ogół powyższych deliberacji w spójną wiązkę konkluzji i wniosków z weryfikacji dochodzimy do następujących spostrzeżeń:

Ostatnia wypowiedź polemiczna Jacka Chachaja nie spowodowała zmiany stanowiska, jakie skłonny byłem zajać uprzednio wobec Jego publikacji Lublin - miasto Rychezyy? Lubelskie szkice historyczne XI-XIV wieku w jej niedawnym oglądzie recenzyjnym. Wszystkie z poczynionych w nim uwag i zastrzeżeń uznaję w dalszym ciagu za uzasadnione już to na gruncie źródłowym, już to metodologicznym.

Jakiegokolwiek analitycznego rozwinięcia nie doczekała się ze strony J. Chachaja czołowa hipoteza o Rychezie jako potencjalnej założycielce Lublina i zarazem fundatorce najstarszej tamtejszej świątyni, obsługiwanej przez benedyktynów, podobnie jak pogląd o możliwej XI-wiecznej genezie świątyni pw. Trójcy Świętej na Wzgórzu Zamkowym, co sprawia, iż propozycje te zasilają tylko rodzinę „faktów historiograficznych”, niemających zakorzenienia w „faktach historycznych” i „faktach źródłowych”. Obszerna ich krytyka, przeprowadzona w poprzedniej mojej wypowiedzi, zachowuje więc pełną aktualność.

Pod naporem krytyki ustępuje też w całej rozciagłości hipoteza o rzekomo możliwym rezydowaniu w Lublinie (i ewentualnie Kocku) wygnanych z Kijowa Gertrudy i Izjasława, za którym to rozwiązaniem nie przemawia żadne świadectwo źródłowe, a przywoływane przez J. Chachaja przekazy polskie (inwentarz majątkowy biskupstwa płockiego oraz wiadomość o nadaniu klucza kockiego biskupstwu płockiemu z Liber beneficiorum Jana Długosza) nie wnoszą żadnych nowych i wiarygodnych elementów do tej rekonstrukcji.

Pod poważnym znakiem zapytania należy postawić tezę, iż lubelski ośrodek grodowy istniał przed druga połową XII w., skoro dotychczasowe wyniki rozpoznań kompetentnych w tym zakresie archeologów nie pozwoliły podnieść tej tezy do stopnia pewności, 
rozchodząc się nieraz w sposób zasadniczy. W sukurs owej tezie w żadnym wypadku nie przychodzą natomiast przekazy pisane, które - wobec pierwszej w dziejach Lublina pewnej daty 1198 (Album klasztoru bożogrobców w Miechowie) - nie sugerują zbyt długiego istnienia tego ośrodka grodowego w odleglejszej przeszłości (X-XI w.).

Mimo dopuszczenia przez J. Chachaja do głosu w kilku miejscach własnych wywodów późnych, nowożytnych i nieweryfikowalnych tradycji lokalnych, mających wystąpić w roli narzędzi pomocniczych w rekonstrukcji najdawniejszych i najsłabiej oświetlonych wieków Lublina, nie uważałem i nie uważam takiego postępowania za uzasadnione metodycznie, ponieważ zabieg ten - mimo pozornej użyteczności - nie może, poza zwróceniem uwagi na te świadectwa, poszerzyć rezerwuaru naszej wiedzy o nowe, metodycznie sprawdzalne fakty historyczne z epoki średniowiecza. Kluczem do rekonstrukcji nawet najbardziej skomplikowanych wydarzeń, relacjonowanych przez małomówne i trudne w egzegezie współczesne im przekazy pisane, musi pozostać wyostrzenie narzędzi źródłoznawczej pracy nad tekstem, co przynosi pozytywne rezultaty, jak widać na przykładzie przeprowadzonego powyżej drobiazgowego rozbioru krytycznego świadectw o najeździe Daniela halickiego na Lublin w 1244 r.

Nie podzielam wreszcie stanowiska mojego Oponenta w sprawie zakresu możliwości stawiania hipotez i ich miejsca w procesie poznania historycznego. Choć z oczywistych względów praktyka badawcza nie może się bez nich obejść, to jednak operowanie nimi w zbyt szerokiej skali jest w wysokim stopniu rozwiązaniem wadliwym, czego najdonioślejszymi przykładami są tzw. piętrowe hipotezy czy argumenty ex silentio fontis. Zbytnie obciążanie nimi jakiejkolwiek pracy naukowej nie przyczynia się do poszerzenia pola poznawczego i nie może z obiektywnych względów nigdy uzyskać aprobaty.

Wydaje się też, że dalszy dialog z J. Chachajem nie przyniesie już - przynajmniej z mojej strony - nowych spostrzeżeń badawczych. Nie chcąc przeto nadwerężać cierpliwości czytelników śledzących tę dyskusję, przedkładam zarazem całokształt ogłoszonych uwag recenzyjnych pod osąd innych obserwatorów debaty, im pozostawiając werdykt, której ze stron należy przyznać rację. Logiczną konsekwencją takiego stanowiska jest fakt, iż na obecnej wypowiedzi mój udział w tej dyskusji już się zamyka. Sentencjonalnie dodam jeszcze tylko za Gerardem Labuda, że „,w wojnach uczonych na szczęście nie ma ani pokonanych, ani zwyciężonych; są tylko przekonani albo nieprzekonani. I takie jest motto naszej dyskusji” (G.L., Głos w dyskusji, NP 69 (1988), s. 215, por. też s. 220). Toteż mimo pełnego uznania i szacunku dla pomysłowości badawczej mojego Adwersarza, objawionej w ostatniej książce Lublin - miasto Rychery? Lubelskie szkice historyczne XI-XIV wiek $u$, konsekwentnie pozostaję po stronie nieprzekonanych zawartą w niej autorska hipotetyczną wizją najdawniejszych stuleci lubelskiego ośrodka grodowego (i zarazem kościelnego). Dalsze jego dzieje (od przywileju Władysława Łokietka z 1317 r. symbolicznie poczynając) to już zupełnie inna historia. 